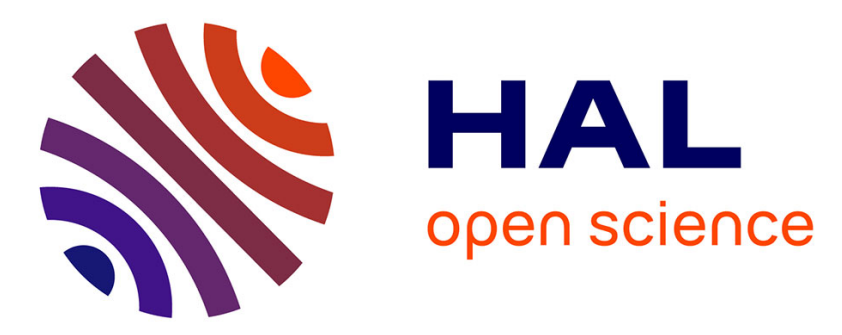

\title{
Eco-CaMnOx: A Greener Generation of Eco-catalysts for Eco-friendly Oxidation Processes
}

Camille Bihanic, Sebastien Diliberto, Franck Pelissier, Eddy Petit, Clotilde Boulanger, Claude Grison

\section{- To cite this version:}

Camille Bihanic, Sebastien Diliberto, Franck Pelissier, Eddy Petit, Clotilde Boulanger, et al.. EcoCaMnOx: A Greener Generation of Eco-catalysts for Eco-friendly Oxidation Processes. ACS Sustainable Chemistry \& Engineering, 2020, 8 (10), pp.4044 - 4057. 10.1021/acssuschemeng.9b05444 . hal-03083124

\section{HAL Id: hal-03083124 https://hal.science/hal-03083124}

Submitted on 18 Dec 2020

HAL is a multi-disciplinary open access archive for the deposit and dissemination of scientific research documents, whether they are published or not. The documents may come from teaching and research institutions in France or abroad, or from public or private research centers.
L'archive ouverte pluridisciplinaire HAL, est destinée au dépôt et à la diffusion de documents scientifiques de niveau recherche, publiés ou non, émanant des établissements d'enseignement et de recherche français ou étrangers, des laboratoires publics ou privés. 
archives-ouvertes

\section{Eco-CaMnOx: A Greener Generation of Eco-catalysts for Eco-friendly Oxidation Processes}

Camille Bihanic, Sebastien Diliberto, Franck Pelissier, Eddy Petit, Clotilde Boulanger, Claude Grison

\section{To cite this version:}

Camille Bihanic, Sebastien Diliberto, Franck Pelissier, Eddy Petit, Clotilde Boulanger, et al.. EcoCaMnOx: A Greener Generation of Eco-catalysts for Eco-friendly Oxidation Processes. ACS Sustainable Chemistry \& Engineering, American Chemical Society, 2020, 8, pp.4044 - 4057. 10.1021/acssuschemeng.9b05444 . hal-03083124

\section{HAL Id: hal-03083124 \\ https://hal.archives-ouvertes.fr/hal-03083124}

Submitted on 18 Dec 2020

HAL is a multi-disciplinary open access archive for the deposit and dissemination of scientific research documents, whether they are published or not. The documents may come from teaching and research institutions in France or abroad, or from public or private research centers.
L'archive ouverte pluridisciplinaire HAL, est destinée au dépôt et à la diffusion de documents scientifiques de niveau recherche, publiés ou non, émanant des établissements d'enseignement et de recherche français ou étrangers, des laboratoires publics ou privés. 


\title{
1. Eco-CaMnO ${ }_{x}$ A Greener Generation of Eco-catalysts for Eco-friendly ${ }_{2}$ Oxidation Processes
}

\author{
3 Camille Bihanic, Sébastien Diliberto, Franck Pelissier, Eddy Petit, Clotilde Boulanger, \\ 4 and Claude Grison*
}

Cite This: https://dx.doi.org/10.1021/acssuschemeng.9b05444

Q. Read Online

\section{ACCESS |}

山ll Metrics \& More

回 Article Recommendations

S1 Supporting Information

5 ABSTRACT: Owing to the alarming problems of depletion of 6 mineral resources and ever-growing pollution by metallic elements, 7 biosourced catalysts were prepared from Mn-accumulating plant 8 species from a large-scale program of ecological rehabilitation of 9 mining sites. This new generation of catalysts, "Eco-CaMnO${ }_{x}$ " 10 catalysts, were obtained directly from a controlled thermal treatment 11 of four species of Grevillea genus, a Mn-rich biomass, and without 12 any further chemical treatment. Eco-CaMnO${ }_{x}$ catalysts were 13 characterized by microwave plasma-atomic emission spectrometer, 14 X-ray powder diffraction spectroscopy, high-resolution transmission 15 electron microscopy, and scanning transmission electron micros16 copy-energy-dispersive X-ray spectroscopy. These analyses revealed 17 a natural richness in two unusual and valuable mixed calcium-

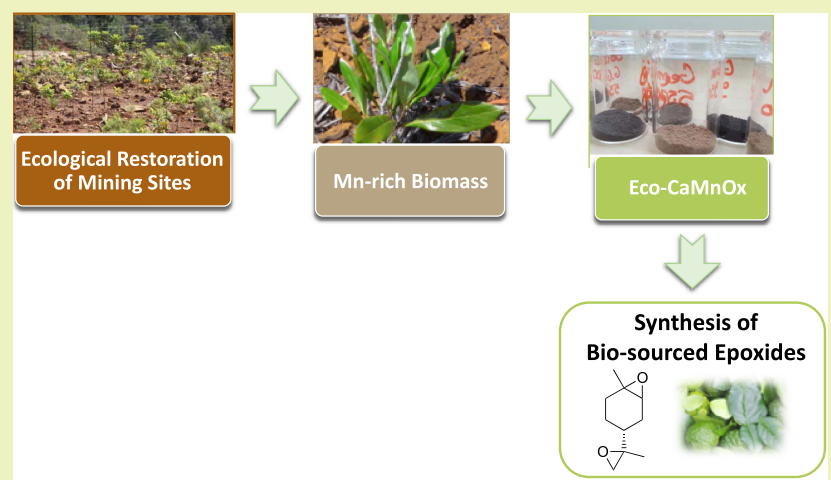
18 manganese oxides: $\mathrm{Ca}_{2} \mathrm{Mn}_{3} \mathrm{O}_{8}$ and $\mathrm{CaMnO}_{3}$. The high efficiency of Eco-CaMnO${ }_{x}$ catalysts was demonstrated via the epoxidation of 19 various biosourced terpenes and lipids, using the mixture $\mathrm{H}_{2} \mathrm{O}_{2} / \mathrm{NaHCO}_{3}$ as a green co-oxidant. This study demonstrated not only 20 the high potential of Eco-CaMnO${ }_{x}$ catalysts as alternatives to oxidative reagents prohibited by $\mathrm{REACH}$ regulation but also the 21 efficient synthesis of biosourced epoxides, which can be used as monomers for the preparation of biodegradable polymers. Finally, 22 the original composition of Eco-CaMnO $x$ catalysts led to distinctive catalytic behaviors compared to previously studied Eco-Mn and 23 Pyr-Mn, allowing the preparation of sensitive epoxides such as linalool epoxide.

24 KEYWORDS: rehabilitation of mining sites: phytoextraction, biosourced $\mathrm{Mn}$ catalyst, $\mathrm{Ca}-\mathrm{Mn}$ cluster, sustainable oxidation, eco-catalysis

25

26 Along with the increase of the world's population, which keeps 27 demanding a higher standard of living, the claim for mineral 28 resources is also rising. While several concerns have been 29 raised over the elemental sustainability, the depletion of "trace 30 metallic elements" (or "TEs") is intensifying. ${ }^{1}$ Growing 31 exploitation of mineral resources is one of the main causes 32 for the serious dissemination of TEs throughout the environ33 ment. TEs are among the most harmful pollutants. As they are 34 not biodegradable, their wide dispersion into different 35 ecosystems has raised concerns over their potential risks on 36 human health and the environment. ${ }^{2}$

37 New Caledonia provides a demonstrative case of this 38 situation. The New Caledonian lagoon is the largest in the 39 world, being classified as one of the UNESCO World Heritage 40 Sites. New Caledonia is one of the highest biodiversity 41 "hotspots" in the world. ${ }^{3}$ This high biodiversity results from 42 the unusual composition of its soil, which is rich in heavy 43 metals, particularly in nickel. However, nickel in soils also 44 implies intensive mining activities. ${ }^{4}$ Nickel mines are opencast. 45 Excavations to access deep nickel lodes require the removal of 46 topsoil, upper soil horizons, and vegetation. The removal of the plant cover leads to the destruction of biodiversity, which 47 promotes soil erosion. 5 The leaching of bare soils drags the 48 sediments away into the streams near mining sites and then 49 into the lagoon, threatening the New Caledonian coral reef. ${ }^{7,8} 50$ This erosion also leads to dramatic events in the neighbor- 51 hood, such as landslides.

The rehabilitation of mining sites is becoming a major 53 priority. Over the last decade, our laboratory has led a large- 54 scale program of ecological restoration of mining sites by the 55 reintroduction of a vegetal cover, based on the rich endemic 56 biodiversity of New Caledonia. Depending on the location of 57 the mining site, pioneer species adapted to local constraints 58 were selected. Among these species, many have the capacity to 59 concentrate heavy metals from the soils into their aerial 60 parts. $^{9-11}$ Manganese accumulators are the most widespread 61 and the most adapted to the restoration of mining sites. In 62

Received: September 13, 2019

Revised: January 14, 2020

Published: January 24, 2020 


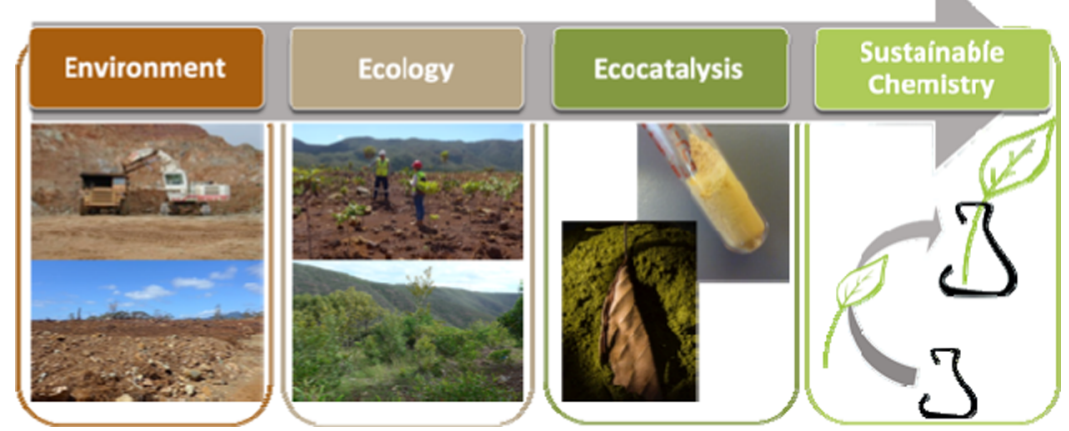

Figure 1. From the ecological restoration of New Caledonian mining sites to ecocatalysis.

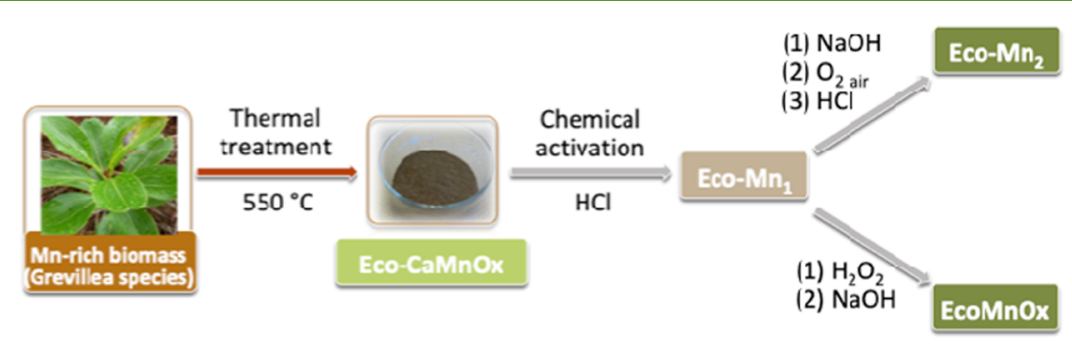

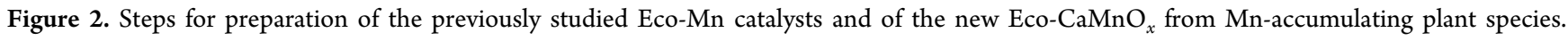

63 particular, species of the genus Grevillea (Proteaceae) are 64 considered as the leading species for restoration, representing 65 about $58 \%$ of the species reintroduced by our group (Figure $661) .{ }^{12,13}$

67 As such ecological programs could represent an economic 68 cost for mining operators, our group has combined restoration 69 with economic outlets. Taking advantage of the adaptive 70 capacity of these particular plants to accumulate heavy metals, 71 it is possible to directly turn metal-rich leaves into green and 72 efficient catalysts used in organic chemistry. This original 73 valorization of biomass has opened a new perspective in 74 sustainable chemistry: "eco-catalysis" (Figure 1). ${ }^{14,15}$ The 75 catalysts coming from biomass, named eco-catalysts (Eco$76 \mathrm{M}$ ), associate the phytoextracted metal with many physio77 logical elements essential for plant metabolism. These 78 polymetallic systems create original chemical species and 79 generate synergetic catalytic effects between their components. $80 \mathrm{~A}$ wide range of eco-catalysts has been prepared and used in 81 many revisited mechanisms of chemistry, such as green 82 oxidation, ${ }^{16-19}$ green reduction, ${ }^{20,21}$ Lewis acid catalysis, ${ }^{22-28}$ 83 and cross-coupling reactions. ${ }^{15,29-31}$

84 Concerning manganese, two generations of Eco-Mn catalysts 85 were prepared from $\mathrm{Mn}$-accumulating plant species belonging 86 to the genus of Grevillea (Figure 2). In each case, the first step 87 was the preparation of an intermediate Eco- $\mathrm{Mn}_{1}$. It was based 88 on a controlled thermal treatment of Mn-rich biomass, 89 followed by a chemical activation by $\mathrm{HCl} .{ }^{16}$ From Eco- $\mathrm{Mn}_{1}$, 90 two oxidative eco-catalysts were formed by a sequential 91 addition of either $\mathrm{NaOH} / \mathrm{O}_{2} / \mathrm{HCl}\left(\mathrm{Eco}-\mathrm{Mn}_{2}\right)^{16}$ or $\mathrm{H}_{2} \mathrm{O}_{2} /$ $92 \mathrm{NaOH}\left(\right.$ Eco- $\left.^{-\mathrm{MnO}_{x}}\right)$. $^{17}$

93 Eco-Mn revealed an original polymetallic composition 94 resulting in marked Brønsted and Lewis acidities and displayed 95 superior catalytic performances than conventional $\mathrm{Mn}$ 96 catalysts. For example, Eco- $\mathrm{Mn}_{1}$ was successfully employed 97 in the aminoreduction of ketones ${ }^{20}$ and constitutes the first 98 example of reduction promoted by a Mn-based catalyst. Eco$99 \mathrm{Mn}_{2}$ and Eco- $\mathrm{MnO}_{x}$ led to a practical and elegant solution to the long-standing challenge of oxidative cleavage of 1,2-diols 100 into aldehyde or ketones. ${ }^{17,18}$ Supported Eco- $\mathrm{Mn}_{1}$ provided 101 also a huge potential as green catalysts for valuable 102 epoxidation. ${ }^{18}$ Finally, Eco- $\mathrm{Mn}_{1}$ acted as "Janus catalysts" by 103 promoting tandem sequences of multicomponent type 104 oxidations (synthesis of substituted pyridines) and cyclizations 105 (synthesis of $p$-cymene). ${ }^{16}$ Comparison of their properties to 106 that of commercial salts highlighted the superior catalytic 107 activities of Eco-Mn.

108

Recently we reported an extensive structural study of Eco- 109 $\mathrm{Mn}_{1}$, characterized by inductive coupled plasma-mass spec- 110 troscopy, X-ray powder diffraction spectroscopy (XRPD), and 111 $\mathrm{X}$-ray absorption spectroscopy (XANES and EXAFS), 112 completed with density functional theory calculations. ${ }^{32}$ In a 113 systematic analysis, we also analyzed the thermal residues, from 114 New Caledonian Mn-accumulating plant species of Grevillea 115 generated before the chemical activation, by XPRD (Figure 2). 116 We detected a polymetallic oxide (a mixed manganese- 117 calcium oxide, $\mathrm{Ca}_{2} \mathrm{Mn}_{3} \mathrm{O}_{8}$ ) instead of polymetallic chlorides as 118 for Eco- $\mathrm{Mn}_{1}$ and Eco- $\mathrm{Mn}_{2}$. 119

While rare examples have described the use of mixed $\mathrm{Mn}-120$ Ca oxide nanoparticles as oxidants, ${ }^{33,34}$ no description was 121 found for the use of $\mathrm{Ca}_{2} \mathrm{Mn}_{3} \mathrm{O}_{8}$ in organic synthesis. However, 122 mixed $\mathrm{Mn}-\mathrm{Ca}$ oxides display biomimetic oxidative properties 123 of the natural cofactor $\mathrm{CaMn}_{4} \mathrm{O}_{5}$ of Photosystem II. Indeed, 124 $\mathrm{CaMn}_{4} \mathrm{O}_{5}$ performs the oxidation of water during the 125 photosynthesis process, ${ }^{35}$ and the complex $\mathrm{Ca}_{2} \mathrm{Mn}_{3} \mathrm{O}_{8}$ presents 126 similar oxidative activities in the electrochemical oxidation of 127 water. $^{36-38}$

The above facts prompted us to further structurally 129 characterize these new potential oxidative eco-catalysts, 130 which we named Eco-CaMnO${ }_{x}$. We investigated the mineral 131 composition of Eco-CaMnO${ }_{x}$ by microwave plasma-atomic 132 emission spectrometer (MP-AES) and their crystalline 133 composition by XRPD. The morphology of Eco-CaMnO ${ }_{x} 134$ was analyzed by high-resolution transmission electron 135 microscopy (HRTEM), and the structural distribution of 136 


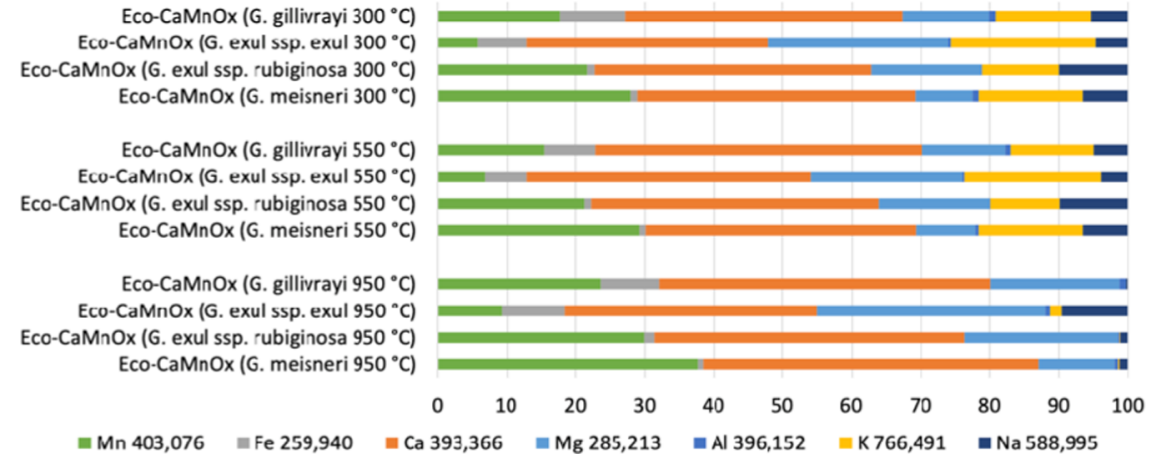

Figure 3. Histogram representing the relative weight percentages of elements in Eco-CaMnO$x$ catalysts, prepared from different plant species of Grevillea and thermal treatments, determined by MP-AES analyses.

137 mineral species was mapped by scanning transmission electron 138 microscopy-energy-dispersive X-ray spectroscopy (STEM139 EDX).

140 The oxidative potential of Eco-CaMnO$x$ catalysts was then 141 investigated in the epoxidation of terpenes with new challenges 142 that would meet the principles of green chemistry: (1) 143 developing a "waste-free" process to prepare catalysts, by 144 suppressing the acidic and basic activation steps; (2) 145 generating catalysts with high catalytic oxidative performances; 146 and (3) providing an eco-friendlier synthesis of biosourced 147 epoxides.

\section{EXPERIMENTAL SECTION}

149 Chemicals. All materials and reagents were purchased from Sigma150 Aldrich and were used without further purification.

151 Preparation of Eco-CaMnO ${ }_{x}$ Catalysts. Eco-CaMnO ${ }_{x}$ were 152 prepared from harvested leaves of $\mathrm{New}$ Caledonian manganese153 accumulating plants: Grevillea exul ssp. exul, Grevillea exul ssp. 154 rubiginosa, Grevillea gillivrayi, and Grevillea meisneri. Plant leaves were 155 coming from the litter of the plants. Harvests are made respecting 156 legal authorizations. Harvested biomass was air-dried at room 157 temperature (rt) and grinded. The obtained powder was thermally 158 treated in an oven under air flow at 300,550 , or $950{ }^{\circ} \mathrm{C}$ for $6 \mathrm{~h}$.

159 Preparation of Synthetic Catalysts. Synthetic ashes were 160 obtained by mixing all together well-chosen commercial metallic 161 salts, so that the relative percentage of metallic elements in the 162 starting mixture was exactly the same as in the leaves of Grevillea exul 163 ssp. rubiginosa. The salt mixture was then thermally treated at $550{ }^{\circ} \mathrm{C}$ 164 following the same procedure as used for $\mathrm{Eco}^{-\mathrm{CaMnO}}{ }_{x}$. The chosen 165 salts were the following: manganese malate trihydrate $\left(\mathrm{MnC}_{4} \mathrm{H}_{4} \mathrm{O}_{5}\right.$. $\left.1663 \mathrm{H}_{2} \mathrm{O}\right)$, calcium oxalate $\left(\mathrm{CaC}_{2} \mathrm{O}_{4} \cdot 2 \mathrm{H}_{2} \mathrm{O}\right)$, iron phosphate $\left(\mathrm{FePO}_{4}\right.$. $\left.1672 \mathrm{H}_{2} \mathrm{O}\right)$, magnesium phosphate $\left(\mathrm{Mg}_{3}\left(\mathrm{PO}_{4}\right)_{2} \cdot x \mathrm{H}_{2} \mathrm{O}\right)$, sodium chloride $168(\mathrm{NaCl})$, potassium chloride $(\mathrm{KCl})$, and aluminum oxalate $\left(\mathrm{Al}_{2} \mathrm{C}_{6} \mathrm{O}_{12}\right.$. $\left.169 x \mathrm{H}_{2} \mathrm{O}\right)$.

$170 \mathrm{Ca}_{2} \mathrm{Mn}_{3} \mathrm{O}_{8}$ was synthesized by grinding $\mathrm{CaCO}_{3}(4 \mathrm{mmol}, 400 \mathrm{mg})$ 171 and $\mathrm{MnCO}_{3}(6 \mathrm{mmol}, 690 \mathrm{mg})$ in a mortar until the obtained powder 172 was homogeneous. The powder was then thermally treated in an oven 173 under air flow at $800{ }^{\circ} \mathrm{C}$ for $18 \mathrm{~h}$.

174 Epoxidation of Alkenes. In a typical procedure, the alkene (1.6 $175 \mathrm{mmol}, 1$ equiv), the catalyst ( $8 \mu \mathrm{mol}, 0.005$ equiv $\mathrm{Mn}$ ), and $\mathrm{NaHCO}_{3}$ $176(8 \mathrm{mmol}, 5$ equiv) were stirred in a mixture of acetone $(20 \mathrm{~mL})$ and 177 water $(20 \mathrm{~mL})$ at room temperature for $10 \mathrm{~min} . \mathrm{H}_{2} \mathrm{O}_{2}(30 \% \mathrm{w} / \mathrm{w}$ in $178 \mathrm{H}_{2} \mathrm{O}, 8 \mathrm{mmol}, 5$ equiv) was added dropwise during $2 \mathrm{~h}$ in the mixture 179 while stirring. After $2 \mathrm{~h}$, the catalyst was filtered off and the reaction 180 mixture was extracted with ethyl acetate. The organic phases were 181 gathered and dried with $\mathrm{Na}_{2} \mathrm{SO}_{4}$. The solvent was then removed by 182 evaporation.

\section{RESULTS AND DISCUSSION}

Preparation and Characterization of Eco-CaMnO 184 Catalysts. Preparation of Eco-CaMnO ${ }_{x}$ Catalysts. Eco- 185 $\mathrm{CaMnO}_{x}$ catalysts were prepared from Mn-rich biomass. 186 Four species of the Grevillea genus are mainly used to 187 rehabilitate mining sites across both provinces in New 188 Caledonia: G. gillivrayi, G. meisneri, G. exul ssp. exul, and G. 189 exul ssp. rubiginosa. Plant leaves were harvested by hand from 190 the plant litter, on the mining sites, which are currently 191 rehabilitated by our group.

192

In this study, two parameters were studied to investigate 193 their influence on Eco-CaMnO ${ }_{x}$ catalytic properties: the plant 194 species, from which the catalysts were prepared, and the 195 temperature of the thermal treatment. The dried leaves, from 196 each of the four species of the Grevillea genus, were thermally 197 treated in an oven, under air flow, at 300, 550, or $950{ }^{\circ} \mathrm{C}$ for 6198 $\mathrm{h}$, to destroy the organic matter. Indeed, these temperatures 199 were chosen according to the literature, as different manganese 200 oxides could be formed depending on the corresponding 201 heating temperature: $\mathrm{MnO}_{2}, \mathrm{Mn}_{2} \mathrm{O}_{3}$, or $\mathrm{Mn}_{3} \mathrm{O}_{4} \cdot{ }^{39,40}$ Eco- 202 $\mathrm{CaMnO}_{x}$ catalysts were then characterized by MP-AES, XRPD, 203 HRTEM, and STEM-EDX mapping.

MP-AES Analysis of Eco-CaMnO ${ }_{x}$ Catalysts. Metallic 205 composition of intact Mn-accumulating plant leaves and of 206 Eco-CaMnO${ }_{x}$ catalysts, resulting from different plant species 207 and thermal treatments, was studied by MP-AES analyses. 208 Analyses were performed in triplicate for each sample to 209 determine the standard deviation of the measurement (Table 210 S1).

The results showed that $\mathrm{Mn}$ was the major transition metal 212 in all eco-catalysts ( 1 to $16.1 \mathrm{wt} \%$ ), except for Eco-CaMnO ${ }_{x} 213$ (G. exul ssp. exul $300{ }^{\circ} \mathrm{C}$ ) (Figure 3). As Ca, Mg, Na, K, and $214 \mathrm{f3}$ $\mathrm{Fe}$ are essential mineral components of plants, they were found 215 in Eco-CaMnO${ }_{x}$ catalysts, $\mathrm{Ca}$ being the major mineral element 216 for every eco-catalyst. Interestingly, the composition of Eco- 217 $\mathrm{CaMnO}_{x}$ catalysts derived from different plants of the same 218 species was quite similar, as shown by low RSD (Table S1). 219 This reproducibility of composition within species could be 220 explained by the harvest timing. ${ }^{13}$ Indeed, leaves were 221 harvested when they became a vegetal litter: they have the 222 highest Mn concentration for each species. As a result of the 223 accumulating specificity of each plant species, the chemical 224 composition appeared different between Eco-CaMnO $\mathrm{Cata}_{x} 225$ lysts.

Within a species the heating temperature at 550 and $950{ }^{\circ} \mathrm{C} 227$ did not have much influence on the chemical composition. But 228 at $300{ }^{\circ} \mathrm{C}$ the elements were less concentrated. This might be 229 
Table 1. Crystalline Species Identified in Eco-CaMnO ${ }_{x}$ Catalysts and in Synthetic Ash Control

\begin{tabular}{|c|c|c|c|c|c|c|c|c|}
\hline & $\mathrm{CaCO}_{3}$ & $\mathrm{CaSO}_{4}$ & $\mathrm{KCl}$ & $\mathrm{Ca}_{2} \mathrm{Mn}_{3} \mathrm{O}_{8}$ & $\mathrm{CaMnO}_{3}$ & $\mathrm{Mn}_{2} \mathrm{O}_{3}$ & $\mathrm{~K}_{2} \mathrm{SO}_{4}$ & $\mathrm{~K}_{3} \mathrm{Na}\left(\mathrm{SO}_{4}\right)_{2}$ \\
\hline Eco-CaMnO${ }_{x}\left(\text { G. gillivrayi } 300{ }^{\circ} \mathrm{C}\right)^{a}$ & $\mathrm{x}$ & & & & & & & \\
\hline Eco-CaMnO $x$ (G. gillivrayi $\left.550{ }^{\circ} \mathrm{C}\right)$ & $\mathrm{x}$ & & $\mathrm{x}$ & $\mathrm{x}$ & & & & $\mathrm{x}$ \\
\hline Eco-CaMnO $x$ (G. gillivrayi $\left.950^{\circ} \mathrm{C}\right)$ & & $\mathrm{x}$ & & & $\mathrm{x}$ & $\mathrm{x}$ & & \\
\hline Eco-CaMnO ${ }_{x}$ (G. exul ssp. exul $\left.550{ }^{\circ} \mathrm{C}\right)^{a}$ & $\mathrm{x}$ & & $\mathrm{x}$ & & & & $\mathrm{x}$ & \\
\hline $\mathrm{Eco}-\mathrm{CaMnO}_{x}\left(\right.$ G. exul ssp. rubiginosa $\left.550^{\circ} \mathrm{C}\right)$ & $\mathrm{x}$ & & $\mathrm{x}$ & $\mathrm{x}$ & & & & $\mathrm{x}$ \\
\hline Eco-CaMnO ${ }_{x}\left(\right.$ G. meisneri $\left.550{ }^{\circ} \mathrm{C}\right)$ & $\mathrm{x}$ & & $\mathrm{x}$ & $\mathrm{x}$ & & & & $\mathrm{x}$ \\
\hline synthetic ash control $\left(550^{\circ} \mathrm{C}\right)$ & & & $\mathrm{x}$ & & & $\mathrm{x}$ & & \\
\hline
\end{tabular}

230 due to a partial degradation of the organic matter at $300{ }^{\circ} \mathrm{C}$ 231 and a total degradation above $550{ }^{\circ} \mathrm{C}$.

232 For further characterizations and experimentations, $G$. 233 gillivrayi was chosen as the model species because the Eco$234 \mathrm{CaMnO}_{x}$ catalysts from G. gillivrayi present an average 235 composition of minerals among the other species.

236 XRPD Analysis of Eco-CaMnO${ }_{x}$ Catalysts. XRPD was 237 performed to deliver insights on the crystalline species present 238 in Eco-CaMnO${ }_{x}$ catalysts and to compare with a reconstituted 239 control of synthetic ashes. The synthetic ash control was 240 obtained by mixing commercial metallic salts chosen so that 241 the relative percentage of metallic elements in the starting 242 mixture was exactly the same as in the leaves of G. exul ssp. 243 rubiginosa, and was followed by a thermal treatment at $550{ }^{\circ} \mathrm{C}$. 244 The identified crystalline phases are summarized in Table 1. $245 \mathrm{Mn}$ was not present in a crystalline form in the eco-catalysts 246 prepared at $300{ }^{\circ} \mathrm{C}$.

247 Interestingly, for the other temperatures, $\mathrm{Mn}$ was present as 248 mixed calcium-manganese oxides. $\mathrm{Ca}_{2} \mathrm{Mn}_{3} \mathrm{O}_{8}$ was identified in 249 all Eco-CaMnO${ }_{x}$ prepared at $550{ }^{\circ} \mathrm{C}$, except for G. exul ssp. 250 exul in which crystalline species of manganese was not 251 observed. The absence of crystalline manganese species in $G$. 252 exul ssp. exul could be linked to a low ratio of Mn/Ca (Table $253 \mathrm{~S} 1)$ preventing the crystallization process. $\mathrm{CaMnO}_{3}$ was 254 identified in all Eco-CaMnO$x$ prepared at $950{ }^{\circ} \mathrm{C} . \mathrm{CaMnO}_{3}$ 255 could result from the degradation of $\mathrm{Ca}_{2} \mathrm{Mn}_{3} \mathrm{O}_{8}$ at high 256 temperature, which was consistent with the calcination 257 temperatures used by $\mathrm{Han}$ et al. to prepare these two 258 complexes. $^{41}$

259 No crystalline mixed manganese-calcium oxide was 260 observed in the synthetic ash control. It suggested that a 261 crystallization mechanism is specific to plant-derived eco262 catalysts and that it cannot be reproduced in a simple mixture 263 of ashes. This difference in crystallization pathways illustrates 264 the vegetal footprint of Eco-CaMnO , which is in accordance 265 with what we reported for Eco- $\mathrm{Mn}_{1} .32$

266 The structure of $\mathrm{Ca}_{2} \mathrm{Mn}_{3} \mathrm{O}_{8}$ has been reported as infinite 267 sheets of $\mathrm{Mn}_{3} \mathrm{O}_{8}{ }^{4-}$ held together by calcium ions. Mn ions are 268 octahedrally coordinated by oxygen atoms and occupy three269 fourths of the octahedral layer sites. The other one-fourth is 270 vacant. ${ }^{37,42}$ The negative charge is further compensated by the 271 presence of $\mathrm{Ca}$ ions in trigonal prismatic sites located above 272 and below layer vacancies. ${ }^{38}$

$273 \mathrm{CaMnO}_{3}$ has a perovskite structure based on corner-shared $274 \mathrm{MnO}_{6}$-octahedra. $\mathrm{Mn}$ ions, present in the oxidation state IV, 275 are located at the center of the octahedron, while each $\mathrm{Ca}$ ion 276 occupies the interoctahedral sites. ${ }^{38,41}$

277 The layered structure of $\mathrm{Ca}_{2} \mathrm{Mn}_{3} \mathrm{O}_{8}$ shares similarities with 278 the cofactor $\mathrm{CaMn}_{4} \mathrm{O}_{5}$, the oxygen-evolving complex present in 279 Photosystem II, which performs the photo-oxidation of water 280 during photosynthesis. The incorporation of calcium into manganese oxides greatly improves water oxidation capaci- 281 ties. $^{43,44}$ Research on a series of manganese-calcium oxides 282 showed that $\mathrm{Ca}_{2} \mathrm{Mn}_{3} \mathrm{O}_{8}$ and $\mathrm{CaMnO}_{3}$ were efficient catalysts 283 for the oxygen evolution reaction and oxygen reduction 284 reaction. Indeed, manganese ions in $\mathrm{Ca}_{2} \mathrm{Mn}_{3} \mathrm{O}_{8}$ and $\mathrm{CaMnO}_{3} 285$ are in the oxidation state IV and they may present interesting 286 oxidative properties similar to $\mathrm{MnO}_{2}$.

HRTEM Analysis of ECO-CaMnO Catalysts (G. gillivrayi, 288 $550{ }^{\circ} \mathrm{C}$ ). HRTEM images of Eco-CaMnO ${ }_{x}$ (G. gillivrayi, 550289 ${ }^{\circ} \mathrm{C}$ ) revealed different particles with various shapes (Figure 4). $290 \mathrm{f4}$

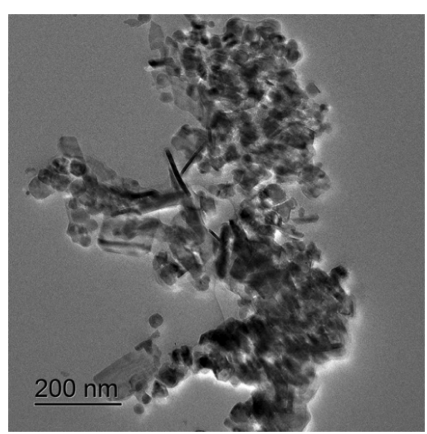

Figure 4. HRTEM image of Eco-CaMnO $x$ catalysts (G. gillivrayi 550 $\left.{ }^{\circ} \mathrm{C}\right)$.

Small round particles of about $10-50 \mathrm{~nm}$ in diameter, lamellar 291 particles of about $10 \mathrm{~nm}$ width over $100 \mathrm{~nm}$ length, as well as 292 thin layer-shape particles seemed blended together into a 293 matrix.

294

STEM-EDX Mapping of ECo-CaMnO ${ }_{x}$ (G. gillivrayi, $\left.550^{\circ} \mathrm{C}\right) .295$ The STEM-EDX analysis was used to establish the chemical 296 composition mapping of Eco-CaMnO $\mathrm{C}_{x}$ catalysts (G. gillivrayi, 297 $550{ }^{\circ} \mathrm{C}$ ) (Figure 5). Manganese, calcium, magnesium, and $298 \mathrm{fs}$ potassium were expectedly present, as shown by MP-AES 299 analyses. The polymetallic structure of Eco-CaMnO ${ }_{x}$ catalysts 300 was supported by the aggregation of manganese, oxygen, and 301 all of the other elements in the round particles, the layer-shape 302 particles, and the matrix. However, it should be noticed that 303 the lamellar particles were exclusively composed of manganese, 304 oxygen, and calcium. The association of these only three 305 elements in a single well-defined shape of particles confirmed 306 the presence of the $\mathrm{Ca}_{2} \mathrm{Mn}_{3} \mathrm{O}_{8}$ complex, and that this complex 307 is organized in lamellar sheets. 308

Extensive structural analyses of the different Eco-CaMnO 309 catalysts showed the presence of two unusual and valuable 310 mixed calcium-manganese complexes: $\mathrm{Ca}_{2} \mathrm{Mn}_{3} \mathrm{O}_{8}$ and 311 $\mathrm{CaMnO}_{3}$. The oxidative potential of the Eco-CaMnO${ }_{x} 312$ catalysts was studied in the epoxidation of alkenes and 313 especially terpenes, as biosourced substrates. 

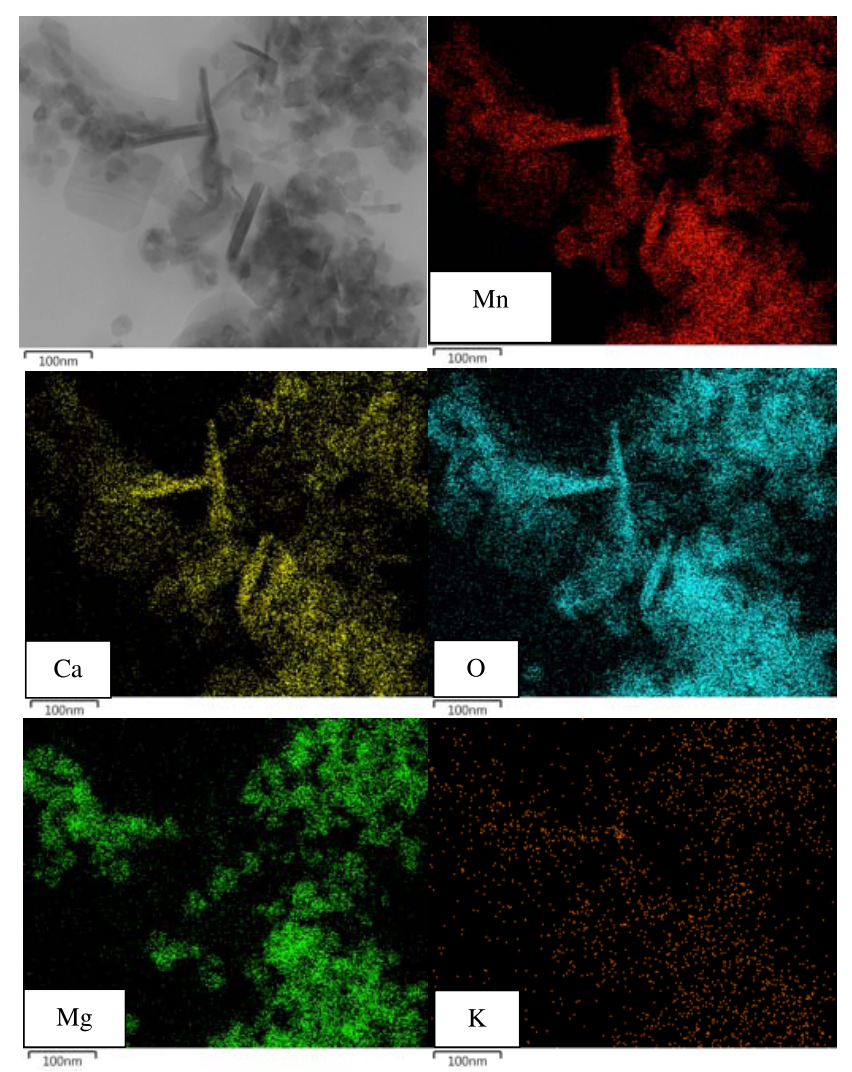

Figure 5. STEM-EDX mapping of Eco-CaMnO ${ }_{x}$ catalysts ( $G$. gillivrayi, $\left.550^{\circ} \mathrm{C}\right)$.

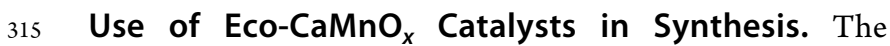
316 standard methods used in fine chemical industries can access 317 epoxidation of substitute alkenes by the use of stoichiometric 318 amounts of organic peroxides or percarboxylic acids, such as 319 meta-chloroperoxybenzoic acid. ${ }^{45}$ Other methods include the 320 use of dimethyldioxirane (also known as Murray's reagent), 321 formed in situ from the reaction between acetone and oxone, ${ }^{46}$ 322 or electrophilic halide source in the presence of a base. ${ }^{47}$ 323 Owing to safety concerns and/or the issue of large production 324 of wastes by these processes, there is a strong need to develop 325 new safer and eco-friendlier methods.

326 Hydrogen peroxide is considered as an ideal alternative 327 oxidant on both environmental and economic grounds. ${ }^{48}$ Not 328 only is it relatively cheap, easily available, and stable at the 329 usual concentration (typically $<60 \mathrm{wt} \%$ ), but it is also a clean 330 oxidizing reagent, as it only forms water as a byproduct. 331 However, it requires an activation to catalyze the oxygen332 transfer process. Many catalytic systems using $\mathrm{H}_{2} \mathrm{O}_{2}$ as the 333 oxidant for epoxidation of alkenes were based on transition334 metal catalysts. ${ }^{49-51}$ However, the use of economically and 335 environmentally unsustainable metals, such as rhenium, ${ }^{52-55}$ 336 vanadium, ${ }^{56,57}$ molybdenum, ${ }^{58-60}$ or tungsten, ${ }^{61-64}$ prompted 337 the research toward inexpensive, abundant, and innocuous 338 transition metals. In particular, iron or manganese revealed to 339 be one of the more promising elements thanks to their 340 relatively low toxicity and their abundance in Earth's crust. ${ }^{65,66}$ 341 Porphyrin-Mn have been extensively investigated as a mimic 342 of cytochrome P450, ${ }^{67-70}$ but suffer from difficulties in 343 synthesis and purification. As they offer synthetical advantages 344 over porphyrin systems, considerable attention was given to 345 Salen-Mn, ${ }^{71,72}$ in particular to the Jacobsen asymmetric epoxidation reaction. ${ }^{73-75}$ However, the homogeneous nature 346 of such metalloporphyrin and Schiff base complexes leads not 347 only to deactivation due to oxidative degradation of the 348 ligand $^{76}$ but also to environmental costs concerning their 349 nonrecyclability. To rectify both problems, heterogenization of 350 these Mn-based catalysts was demonstrated, by grafting on a 351 solid support or immobilization into porous solids, such as 352 silica, polymers, nanoparticles, and zeolites. ${ }^{77-80}$ For example, 353 heterogeneous $\mathrm{Ti}$ silicates are nowadays used at an industrial 354 scale with $\mathrm{H}_{2} \mathrm{O}_{2}$ for conducting epoxidation reactions with very 355 high catalytic and environmental performances. ${ }^{81} 356$

In our previous works, we showed that montmorillonite- 357 supported Eco- $\mathrm{Mn}_{1}$ catalyzed the epoxidation of styrene. Eco- 358 $\mathrm{Mn}_{1}$ contained only $0.31 \mathrm{~mol} \%$ of manganese, a much lower 359 content of manganese than that reported in previously 360 described Mn-derived heterogeneous catalysts. ${ }^{82,83}$ Compar- 361 ison of Eco- $\mathrm{Mn}_{1}$ properties to those of heterogeneous catalysts 362 made by incorporation of commercial $\mathrm{MnCl}_{2} \cdot 4 \mathrm{H}_{2} \mathrm{O}$ and $\mathrm{FeCl}_{3} \cdot 363$ $6 \mathrm{H}_{2} \mathrm{O}$ highlighted the superior catalytic activity of polymetallic 364 species present in Eco- $\mathrm{Mn}_{1}$. These promising results prompted 365 us to investigate the utilization of $\mathrm{Eco}^{-\mathrm{CaMnO}} \mathrm{M}_{x}$ as an 366 epoxidizing agent and to study the possible cooperative 367 catalytic effect between $\mathrm{Ca}$ and $\mathrm{Mn}$.

Optimization of the Conditions for the Epoxidation of $\alpha$ - 369 pinene. The epoxidation of $\alpha$-pinene was chosen as a probe 370 reaction to optimize the reaction conditions. $\alpha$-pinene is a 371 monoterpene mostly found in pine trees, an abundant natural 372 resource. The pinene oxide represents an inexpensive 373 biosourced starting material for the synthesis of flavors, 374 fragrances, and agrochemical and therapeutic substances. ${ }^{84-86} 375$ However, $\alpha$-pinene oxide is a sensitive and reactive substrate, 376 which rearranges easily in acid conditions. ${ }^{87,88}$ The rearrange- 377 ment of $\alpha$-pinene oxide leads to the formation of a wide range 378 of products, which depends largely on the acid-base 379 properties of the catalytic system. Over 200 compounds were 380 reported when the isomerization-reaction temperature was 381 above $100{ }^{\circ} \mathrm{C} .{ }^{87}$ It is well described that Lewis acid sites favor 382 the formation of campholenic aldehyde, pinocarveol, and iso- 383 pinocamphone, whereas Brønsted acid sites result in the 384 formation of trans-carveol, trans-sobrerol, and p-cymene. ${ }^{89-91} 385$ For instance, one of the most desired products resulting from 386 the $\alpha$-pinene oxide is campholenic aldehyde because it is an 387 intermediate for the manufacture of sandalwood fragrances. 388 The epoxidation of $\alpha$-pinene into $\alpha$-pinene oxide remains a 389 challenge because of its isomerization into many different 390 byproducts.

391

In a typical procedure, $\alpha$-pinene, Eco-CaMnO ${ }_{x}$ (G. gillivrayi 392 $\left.550{ }^{\circ} \mathrm{C}\right)$, and $\mathrm{NaHCO}_{3}$ were stirred in a mixture of 393 acetone:water $(1: 1)$ at room temperature for $10 \mathrm{~min} . \mathrm{H}_{2} \mathrm{O}_{2} 394$ ( $30 \% \mathrm{w} / \mathrm{w}$ in $\mathrm{H}_{2} \mathrm{O}$ ) was added dropwise during $2 \mathrm{~h}$ in the 395 mixture while stirring. After $2 \mathrm{~h}$, the catalyst was filtered off and 396 the reaction mixture was extracted with ethyl acetate. The 397 organic layers were gathered and dried with $\mathrm{Na}_{2} \mathrm{SO}_{4}$. The 398 solvent was then removed by evaporation and the reaction 399 products analyzed by gas chromatography-mass spectrometry 400 (GC-MS)/flame ionization detector (FID).

401

Effect of $\mathrm{H}_{2} \mathrm{O}_{2}$ Amount. The effect of the quantity of $\mathrm{H}_{2} \mathrm{O}_{2} 402$ added into the reaction mixture was studied, as an excessive 403 amount of $\mathrm{H}_{2} \mathrm{O}_{2}$ could lead to a decrease in epoxide selectivity 404 by overoxidation. ${ }^{92}$ The conversion, yield, and selectivity 405 followed the same trend (Table 2). Increasing the quantity of $406 \mathrm{t} 2$ $\mathrm{H}_{2} \mathrm{O}_{2}$ increased the conversion, yield, and selectivity before 407 reaching a threshold. Almost total conversion of $\alpha$-pinene 1a 408 
Table 2. Effect of the Amount of $\mathrm{H}_{2} \mathrm{O}_{2}$ and of the Adding Time on the Epoxidation of $\alpha$-pinene ${ }^{a}$

\begin{tabular}{|c|c|c|c|c|c|}
\hline \multirow[b]{2}{*}{ entry } & $1 a$ & $\begin{array}{r}\text { Eco-CaMnOx (G. gilliv } \\
\begin{array}{r}\mathrm{NaHC}^{2} \\
\mathrm{H}_{2} \mathrm{O}_{2}\end{array} \\
\mathrm{H}_{2} \mathrm{O}\end{array}$ & $\begin{array}{l}\left.550^{\circ} \mathrm{C}\right)(0.005 \mathrm{e} \\
(5 \mathrm{eq} .) \\
0 \text { wt\%) } \\
\text { cetone } \\
2 \mathrm{~h}\end{array}$ & & $2 a$ \\
\hline & $\begin{array}{c}\mathrm{H}_{2} \mathrm{O}_{2} \\
\text { (equiv) }\end{array}$ & $\begin{array}{l}\text { addition time } \\
\quad(\min )\end{array}$ & $\begin{array}{c}\text { conversion } \\
(\%)^{b}\end{array}$ & $\begin{array}{l}\text { yield } \\
(\%)^{b}\end{array}$ & $\begin{array}{l}\text { selectivity } \\
(\%)^{b, c}\end{array}$ \\
\hline 1 & 0 & 120 & 0 & 0 & 0 \\
\hline 2 & 1 & 120 & 62 & 21 & 34 \\
\hline 3 & 3 & 120 & 80 & 44 & 55 \\
\hline 4 & 4 & 120 & 77 & 47 & 61 \\
\hline 5 & 5 & 120 & 98 & 64 & 65 \\
\hline 6 & 10 & 120 & 99 & 62 & 63 \\
\hline 7 & 10 & 60 & 98 & 65 & 66 \\
\hline 8 & 10 & 30 & 63 & 41 & 65 \\
\hline
\end{tabular}

${ }^{a}$ Reaction conditions: $\alpha$-pinene ( $1.6 \mathrm{mmol}, 1$ equiv), catalyst ( $8 \mu \mathrm{mol}$, 0.005 equiv $\mathrm{Mn}), \mathrm{NaHCO}_{3}$ (8 mmol, 5 equiv), $\mathrm{H}_{2} \mathrm{O}_{2}$ (30 wt \%), and $\mathrm{H}_{2} \mathrm{O}(20 \mathrm{~mL})$ : acetone $(20 \mathrm{~mL}), \mathrm{rt}, 2 \mathrm{~h} .{ }^{b}$ Conversion, yield, and selectivity were established by FID using biphenyl as internal standard. ${ }^{c}$ Selectivity was calculated as the ratio of yield over conversion.

409 and a yield of $64 \%$ in epoxide 2 a were reached with 5 equiv of $410 \mathrm{H}_{2} \mathrm{O}_{2}$ (Table 2, entry 5). The addition time of $\mathrm{H}_{2} \mathrm{O}_{2}$ in the 411 reaction mixture was also investigated. Although the selectivity 412 in epoxide remained similar by decreasing the addition time, 413 the conversion dropped from $98 \%$ in $1-2 \mathrm{~h}$ (Table 2, entries 6, 4147 ) to $63 \%$ in $30 \mathrm{~min}$ (Table 2, entry 8). These results 415 supported the importance of a slow addition of $\mathrm{H}_{2} \mathrm{O}_{2}$ in 416 oxidative reactions. Indeed, it was reported that a gradual 417 addition of $\mathrm{H}_{2} \mathrm{O}_{2}$ decreased its self-decomposition. ${ }^{93,94}$

418 The selectivity in $\alpha$-pinene oxide gave some information 419 about Eco-CaMnO ${ }_{x}$. The oxygenated byproducts observed, 420 such as campholenic aldehyde, carveol, and iso-pinocamphone, 421 could be explained by the easy opening and rearrangement of 422 the epoxide by Lewis acid sites. This could reveal the presence 423 of many metallic species in our catalysts, like $\mathrm{Fe}, \mathrm{Ca}$, and $\mathrm{Mg}$, 424 which could confer Lewis acid properties to Eco-CaMnO 425 catalysts. As it was reported that $\alpha$-pinene oxide could also 426 rearrange spontaneously in acid or neutral aqueous phase 427 media, ${ }^{90}$ the epoxide was directly engaged in the reaction with 428 and without any catalyst, to test its stability. In the presence of $429 \mathrm{Eco}^{-\mathrm{CaMnO}} \mathrm{Mn}_{x}$ catalysts a conversion of $45 \%$ was observed, 430 whereas it was fully recovered without any catalyst. This result 431 indicated that the epoxide was stable in our conditions, even in 432 the presence of water, and that its rearrangement only occurred 433 in the presence of Eco-CaMnO ${ }_{x}$. This supports the presence of 434 Lewis acid sites in Eco-CaMnO ${ }_{x}$. Allylic oxidation is often a 435 competitive process of epoxidation in the oxidation of cyclic 436 olefins. $^{95,96}$ As both processes could occur simultaneously, it 437 could explain the formation of verbenone, identified among the 438 different byproducts.

439 For the following reactions, 5 equiv of $\mathrm{H}_{2} \mathrm{O}_{2}$ was employed 440 as it represented the smallest amount affording total 441 conversion and high yield in epoxide. The addition time was 442 kept at $2 \mathrm{~h}$.

443 Effect of $\mathrm{NaHCO}_{3}$ Amount. The effect of the quantity of $444 \mathrm{NaHCO}_{3}$ added into the reaction mixture was investigated 445 (Table 3). No conversion of $\alpha$-pinene was observed in the 446 absence of sodium hydrogen carbonate (Table 3 , entry 1 ). 447 This result supported the essential presence of sodium 448 hydrogen carbonate allowing the epoxidation. It is assumed
Table 3. Effect of the Amount of $\mathrm{NaHCO}_{3}$ on the Epoxidation of $\alpha$-pinene ${ }^{a}$

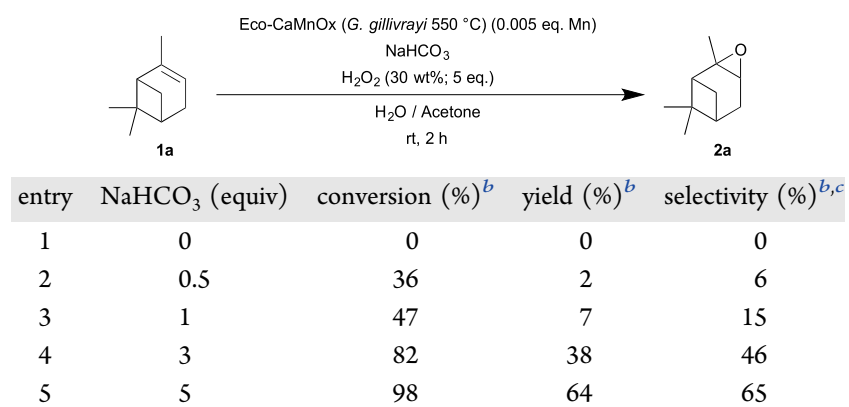

${ }^{a}$ Reaction conditions: $\alpha$-pinene ( $1.6 \mathrm{mmol}, 1$ equiv), catalyst ( $8 \mu \mathrm{mol}$, 0.005 equiv $\mathrm{Mn}$ ), $\mathrm{NaHCO}_{3}, \mathrm{H}_{2} \mathrm{O}_{2}$ (30 wt \%; $8 \mathrm{mmol}, 5$ equiv), and $\mathrm{H}_{2} \mathrm{O}(20 \mathrm{~mL})$ : acetone $(20 \mathrm{~mL}), \mathrm{rt}, 2 \mathrm{~h} .{ }^{b}$ Conversion, yield, and selectivity were established by FID using biphenyl as internal standard. ${ }^{c}$ Selectivity was calculated as the ratio of yield over conversion.

that $\mathrm{NaHCO}_{3}$ and $\mathrm{H}_{2} \mathrm{O}_{2}$ could produce in situ peroxymono- 449 carbonate ions $\left(\mathrm{HCO}_{4}^{-}\right),{ }^{97,98}$ which would react with the $\mathrm{Mn}-450$ eco-catalyst to form the active epoxidizing reagent. Indeed, a 451 neutral or slightly basic $\mathrm{pH}$ (range from 7 to 9) is optimal for 452 this bicarbonate-activated peroxide system, which corresponds 453 to the $\mathrm{pH}$ values of the aqueous phase that ranged from 8.2 to 454 8.8 in our system.

455

An attempt to reduce $\mathrm{NaHCO}_{3}$ quantity resulted in 456 decreasing conversion, yield, and selectivity in epoxide. 457 Therefore, 5 equiv of $\mathrm{NaHCO}_{3}$ seemed to be the lowest 458 quantity giving high conversion and yield (Table 3, entry 5). 459

Effect of Catalyst Loading. The effect of the quantity of 460 Eco-CaMnO ${ }_{x}$ catalysts was then studied using $\alpha$-pinene as the 461 substrate (Table 4). A low quantity of manganese gave high $462 \mathrm{t} 4$ conversion rates. Almost total conversion and $64 \%$ yield were 463 obtained with only 0.005 equiv in manganese (Table 4, entry 464 4). This result is remarkable compared to standard manganese- 465 based catalysts, which usually require to be used in excess. ${ }^{99} 466$

As a control, the reaction was carried out in the absence of 467 Eco-CaMnO $x$ catalysts. The reaction could not occur in the 468 corresponding reaction time, in $2 \mathrm{~h}$ (Table 4, entry 1 ). 469

The oxidative capacity of Eco-CaMnO${ }_{x}$ was also compared 470 to synthetic catalysts (Table 4, entries 7-9). The synthetic 471 $\mathrm{Ca}_{2} \mathrm{Mn}_{3} \mathrm{O}_{8}$ catalyst was prepared following the procedure 472 described by Najafpour et al., ${ }^{38}$ and commercial manganese 473 dioxide was activated.

474

As expected, conversion of $\alpha$-pinene catalyzed by calcium 475 oxide was negligible (Table 4, entry 9). Calcium oxide species 476 alone cannot catalyze the epoxidation of $\alpha$-pinene, since 477 calcium is not electroactive. However, conversion was 478 increased by the addition of calcium to manganese oxide 479 species; yields of 15 and $32 \%$ were obtained with commercial 480 activated $\mathrm{MnO}_{2}$ and synthetic $\mathrm{Ca}_{2} \mathrm{Mn}_{3} \mathrm{O}_{8}$ catalysts, respectively 481 (Table 4, entries 7 and 8). A comparison of these three 482 experiments shows that calcium enhances the reactivity of 483 manganese, suggesting a synergistic effect of mixed calcium- 484 manganese oxides toward epoxidation. These findings suggest 485 that the addition of calcium does not change the oxidation 486 potential of manganese, but might change the dispersion and/ 487 or exposition of manganese, enhancing its reactivity as 488 suggested by the works of Han et al. on mixed calcium- 489 manganese oxides. ${ }^{41}$ 
Table 4. Effect of the Catalyst Loading on the Epoxidation of $\alpha$-pinene ${ }^{a}$

\begin{tabular}{|c|c|c|c|c|c|c|c|}
\hline & & & $\begin{array}{r}\text { Eco-CaMnOx } \\
\mathrm{NaHC} \\
\mathrm{H}_{2} \mathrm{O}_{2}(30 \\
\mathrm{H}_{2} \mathrm{O}\end{array}$ & q. $550^{\circ} \mathrm{C}$ ) & $<0$ & & \\
\hline entry & catalyst & equiv $\mathrm{Mn}$ & conversion $(\%)^{b}$ & yield $(\%)^{b}$ & selectivity $(\%)^{b, c}$ & $\mathrm{TON}^{f}$ & $\mathrm{TOF}^{g}\left(\mathrm{~h}^{-1}\right)$ \\
\hline 1 & $\mathrm{Eco}^{-\mathrm{CaMnO}}{ }_{x}$ & 0 & 0 & 0 & 0 & 0 & 0 \\
\hline 2 & Eco-CaMnO $x$ & 0.001 & 89 & 49 & 55 & 490 & 245 \\
\hline 3 & Eco-CaMnO $x$ & 0.0025 & 97 & 48 & 49 & 192 & 96 \\
\hline 4 & $\mathrm{Eco}^{-\mathrm{CaMnO}}{ }_{x}$ & 0.005 & 97 & 62 & 64 & 124 & 62 \\
\hline 5 & $\mathrm{Eco}^{-\mathrm{CaMnO}}{ }_{x}$ & 0.01 & 94 & 55 & 59 & 55 & 28 \\
\hline 6 & $\mathrm{Eco}^{-\mathrm{CaMnO}}{ }_{x}$ & 0.1 & 91 & 61 & 67 & 6 & 3 \\
\hline 7 & $\mathrm{Ca}_{2} \mathrm{Mn}_{3} \mathrm{O}_{8}$ & 0.005 & 51 & 32 & 63 & 64 & 32 \\
\hline 8 & activated $\mathrm{MnO}_{2}$ & 0.005 & 55 & 15 & 27 & 30 & 15 \\
\hline 9 & $\mathrm{CaO}$ & $d$ & $7^{e}$ & 0 & 0 & & \\
\hline
\end{tabular}

${ }^{a}$ Reaction conditions: $\alpha$-pinene ( $1.6 \mathrm{mmol}, 1$ equiv), the catalyst, $\mathrm{NaHCO}_{3}\left(8 \mathrm{mmol}, 5\right.$ equiv), $\mathrm{H}_{2} \mathrm{O}_{2}\left(30\right.$ wt \%; 8 mmol, 5 equiv), and $\mathrm{H}_{2} \mathrm{O}$ (20 $\mathrm{mL})$ : acetone $(20 \mathrm{~mL}), \mathrm{rt}, 2 \mathrm{~h} .{ }^{b}$ Conversion, yield, and selectivity were established by FID using biphenyl as the internal standard. ${ }^{c}$ Selectivity was calculated as the ratio of yield over conversion. ${ }^{d} 0.02$ equiv Ca was used, corresponding to the quantity of Ca engaged by 0.005 equiv $\mathrm{Mn}$ with Eco$\mathrm{CaMnO}_{x} \cdot{ }^{e}$ Traces of verbenol, carveol, and campholenic aldehyde were detected by GC-MS. ${ }^{f} \mathrm{TON}=$ number of mol of the product formed per mol of catalyst. ${ }^{g} \mathrm{TOF}=$ number of mol of the product formed per mol of catalyst and per unit of time.

491 Interestingly, Eco-CaMnO${ }_{x}$ catalysts gave a twice-higher 492 yield compared to synthetic $\mathrm{Ca}_{2} \mathrm{Mn}_{3} \mathrm{O}_{8}$ (Table 4, entries 4 and 4937 ). The enhanced reactivity of our catalyst might be due to a 494 different structural organization of manganese linked to its 495 vegetal footprint and/or due to the presence of traces of other 496 electroactive metal species.

497 Effect of the Plant Species and the Temperature of the 498 Thermal Treatment Used to Prepare Eco-CaMnO ${ }_{x}$. The 499 different Eco-CaMnO ${ }_{x}$ catalysts prepared from the four species 500 of Grevillea were tested in the epoxidation of $\alpha$-pinene by 501 using the optimized reaction conditions. The influence of the 502 heating temperature during the thermal treatment of biomass 503 was also investigated (Figure 6). For each plant species, each 504 corresponding $\mathrm{Eco}-\mathrm{CaMnO}_{x}$ catalyst showed a potent catalytic 505 activity. These results guarantee that every manganese506 accumulating plant species used in rehabilitation could be 507 valorized afterward by this process.

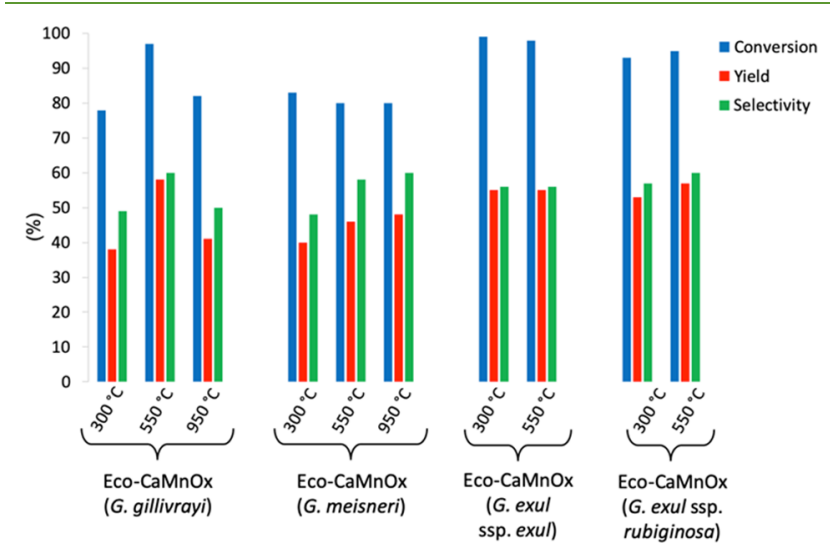

Figure 6. Effect of the plant species and of the temperature of the thermal treatment used to prepare Eco-CaMnO$x$ on the epoxidation of $\alpha$-pinene. Reaction conditions: $\alpha$-pinene ( $1.6 \mathrm{mmol}, 1$ equiv), catalyst $(8 \mathrm{mmol}, 0.005$ equiv $\mathrm{Mn}), \mathrm{NaHCO}_{3}(8 \mathrm{mmol}, 5$ equiv), $\mathrm{H}_{2} \mathrm{O}_{2}$ (30 wt \%; $8 \mathrm{mmol}, 5$ equiv), and $\mathrm{H}_{2} \mathrm{O}(20 \mathrm{~mL})$ : acetone $(20$ $\mathrm{mL}), \mathrm{rt}, 2 \mathrm{~h}$. Conversion, yield, and selectivity were established by FID using biphenyl as internal standard. Selectivity was calculated as the ratio of yield over conversion.
Within a species, the temperature of the thermal treatment 508 did not seem to have much influence on the Eco-CaMnO ${ }_{x} 509$ activities. Surprisingly, no loss of activity was observed for the 510 eco-catalysts formed at $300{ }^{\circ} \mathrm{C}$ despite the residual organic 511 matter. The Eco-CaMnO${ }_{x}$ catalysts of G. gillivrayi and G. 512 meisneri prepared at $950{ }^{\circ} \mathrm{C}$ revealed similar activities as the 513 corresponding Eco-CaMnO${ }_{x}$ catalysts prepared at lower 514 temperatures ( 300 and $550{ }^{\circ} \mathrm{C}$ ). The best catalyst in terms 515 of activity and energy required for its preparation remained the 516 one prepared at $550{ }^{\circ} \mathrm{C}$.

517

The reaction conditions to perform the epoxidation of $\alpha$ - 518 pinene were optimized to reach a good compromise of the 519 high efficiency of the reaction with sustainable and eco- 520 responsible use of chemical products and solvents. In these 521 conditions, almost total conversion was accessed with $65 \% 522$ selectivity in pinene oxide. Longer reaction times were tested, 523 but it only resulted in a decrease in selectivity, the conversion 524 remaining total. This result was in accordance with the high 525 reactivity of pinene oxide and thus its conversion into isomeric 526 products. $^{100,101}$

527

Our system can be advantageously compared to other 528 bicarbonate-activated peroxide systems based on Mn catalysts. 529 For instance, Lane et al. obtained $89 \%$ yield but only in the 530 presence of additives. $^{82} \mathrm{Qi}$ et al. reached $40 \%$ selectivity using 531 $\mathrm{Mn}^{2+}$-exchanged zeolites. ${ }^{92}$

Substrate Scope for the Epoxidation of Terpenes and 533 Lipids by Eco-CaMnO Catalysts. The epoxidation of diverse 534 terpenes and lipids was carried out to evaluate the scope of our 535 process (Table 5).

536 t5

High conversions and yields were obtained with a large 537 variety of terpenes, from cyclic to terminal substrates, which 538 confirmed the efficiency of the method. In some cases, a longer 539 reaction time was needed to reach higher conversions. $\quad 540$

The chemoselectivity of Eco-CaMnO$x$ catalysts was 541 illustrated through the selective epoxidation of terpenes 542 (Table 5, entries 2-8) bearing various functional groups, 543 such as alcohol, ester, or enone, that remained unmodified. 544 The epoxidation of monoterpenes like terpineol, isopulegol, 545 and citronellyl acetate (Table 4, entries 2, 3 and 5) gave total 546 conversion and selectivity. The epoxidation of $(R)-(+)$-limo- 547 nene, linalool, geranyl acetate, $\alpha$-ionone, and $\beta$-ionone gave 548 
Table 5. Substrate Scope for the Epoxidation of Natural Substrates by Ecocatalysts (Eco-CaMnO ${ }_{x}^{a}, \mathrm{Eco}^{-\mathrm{Mn}_{1}}{ }^{18}$ and $^{\mathrm{Pyr}-}$ $\mathrm{Mn}^{120}$ )

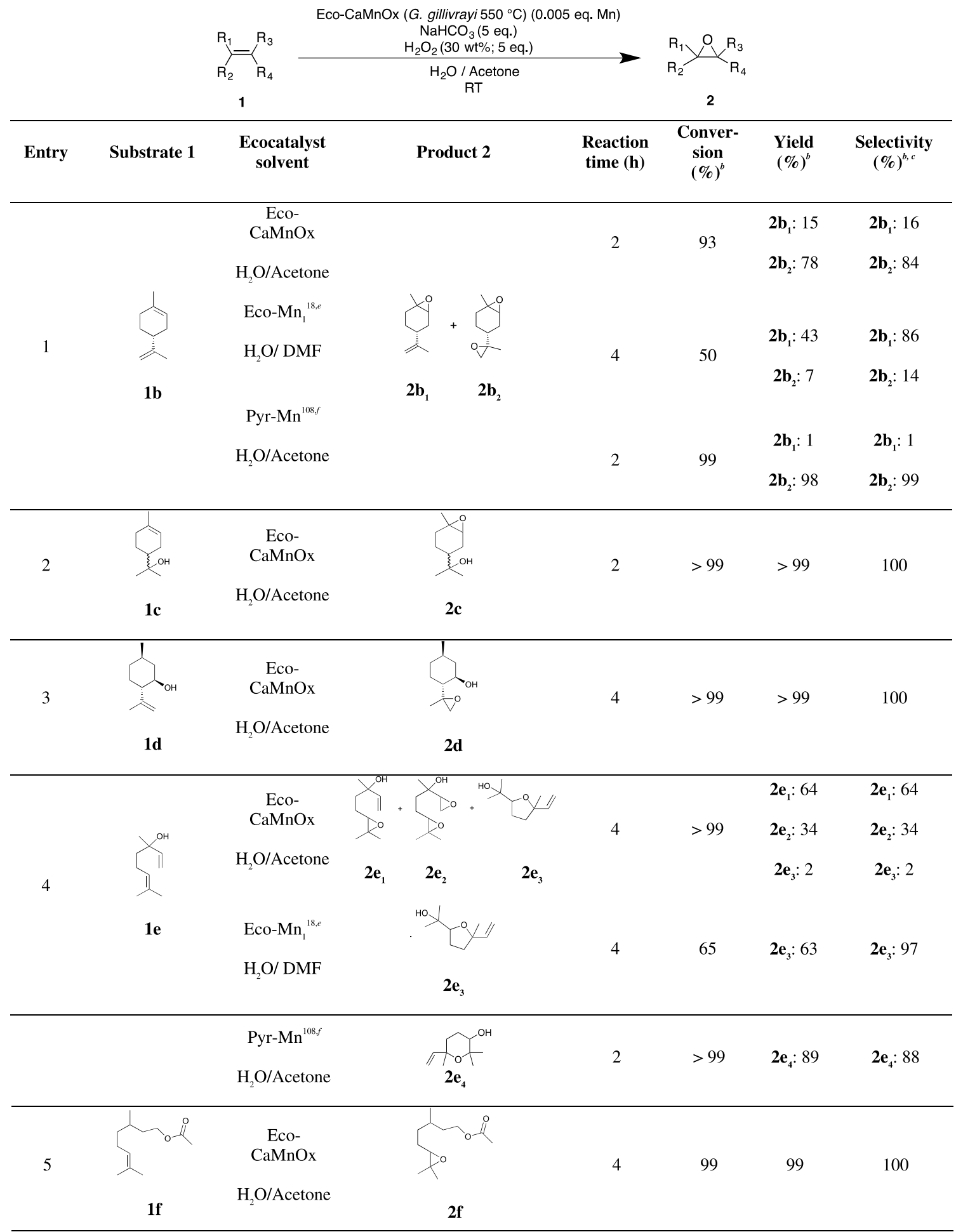


Table 5. continued

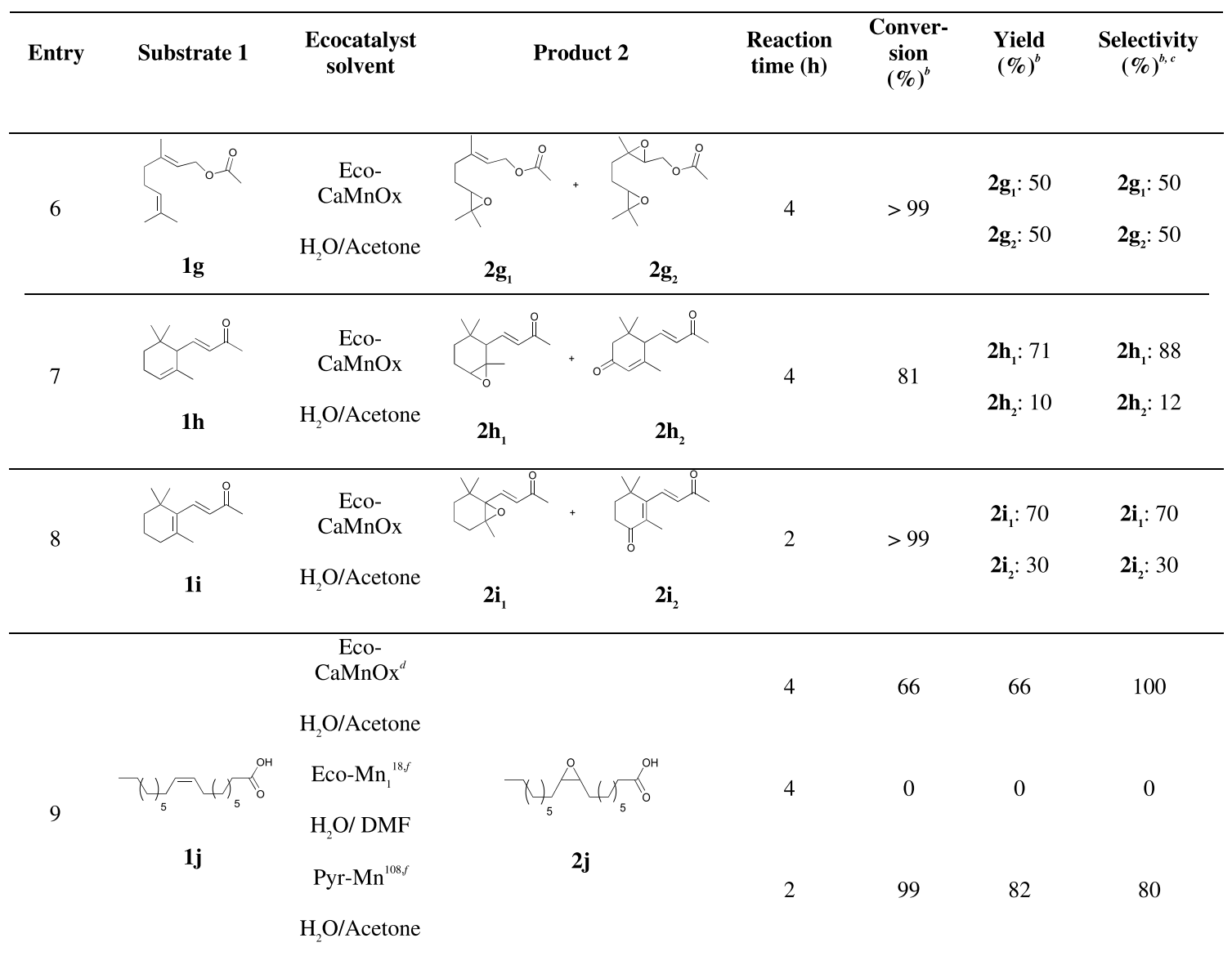

\footnotetext{
${ }^{a}$ Reaction conditions: substrate ( $1.6 \mathrm{mmol}, 1$ equiv), catalyst $(8 \mu \mathrm{mol}, 0.005$ equiv $\mathrm{Mn}), \mathrm{NaHCO}_{3}\left(8 \mathrm{mmol}, 5\right.$ equiv), $\mathrm{H}_{2} \mathrm{O}_{2}(30$ wt $\% ; 8 \mathrm{mmol}, 5$ equiv), and $\mathrm{H}_{2} \mathrm{O}(20 \mathrm{~mL})$ : acetone $(20 \mathrm{~mL})$, rt. ${ }^{b}$ Conversion, yield, and selectivity were established by FID, using biphenyl as internal standard, and then confirmed by ${ }^{1} \mathrm{H}$ NMR from the isolated product. ${ }^{c}$ Selectivity was calculated as the ratio of yield over conversion. ${ }^{d}$ Catalyst: 0.5 equiv Mn. ${ }^{e}$ Terpene ( $0.25 \mathrm{mmol}, 1$ equiv), supported catalyst ( 0.0031 equiv $\left.\mathrm{Mn}\right), \mathrm{NaHCO}_{3}\left(0.05 \mathrm{mmol}, 5\right.$ equiv), $\mathrm{H}_{2} \mathrm{O}_{2}(30 \mathrm{wt} \% ; 0.8 \mathrm{mmol}, 3.2$ equiv), and $\mathrm{H}_{2} \mathrm{O}$ /dimethylformamide (DMF) $(2 \mathrm{~mL}), 0{ }^{\circ} \mathrm{C}, 4 \mathrm{~h} .{ }^{f}$ Terpene $\left(0.18 \mathrm{mmol}, 1\right.$ equiv), catalyst $(0.00006$ equiv $\mathrm{Mn}), \mathrm{NaHCO}_{3}(0.88 \mathrm{mmol}, 5$ equiv), $\mathrm{H}_{2} \mathrm{O}_{2}$ (30 wt \%; $1.75 \mathrm{mmol}, 9.7$ equiv), and $\mathrm{H}_{2} \mathrm{O} /$ acetone $(2.6 \mathrm{~mL}), 30{ }^{\circ} \mathrm{C}, 2 \mathrm{~h}$.
}

549 mono- (Table 5, entries 7 and 8) or diepoxides (Table 5, 550 entries 1,4 , and 6) when the double bonds were electron-rich. 551 In the case of limonene, $84 \%$ of selectivity of diepoxides was 552 observed with very high conversion in $2 \mathrm{~h}$ (Table 4, entry 1 ). 553 In comparison, Eco- $\mathrm{Mn}_{1}$ led to $86 \%$ of monoepoxides, with 554 only $50 \%$ of conversion. ${ }^{18}$ This result highlighted the high 555 reactivity of Eco-CaMnO , which was close to Pyr-Mn. Both 556 mono- and diepoxides are of high interest in the field of 557 biosourced polymers as they both could be used as monomers 558 for the synthesis of polycarbonates, polyethers, polyesters, or 559 poly(hydro)urethanes. ${ }^{102-106}$ Thus, they could represent 560 substitutes for polymers synthesized from bisphenol A or 561 epichlorhydrin, two toxic molecules classified as CMR.

562 In $4 \mathrm{~h}$, the epoxidation of geranyl acetate gave a 563 stoichiometric mixture of mono- and diepoxides (Table 5, 564 entry 6). In consequence, the ester moiety did not deactivate $565 \mathrm{Eco}^{-\mathrm{CaMnO}} \mathrm{Mn}_{x}$ in spite of its basic Lewis properties. The same 566 reaction with 10 equiv of $\mathrm{H}_{2} \mathrm{O}_{2}$ favored the formation of the 567 diepoxide, reaching $79 \%$ of selectivity. It was thus possible to 568 control the ratio monoepoxides/diepoxides by tuning the 569 amount of $\mathrm{H}_{2} \mathrm{O}_{2}$.

570 Unlike Eco-Mn and conventional catalysts, the epoxidation 571 of linalool led mainly to the monoepoxide, with $64 \%$ of 572 selectivity (Table 5, entry 4 ). This result is unusual as the resulting epoxide is highly reactive and acid-sensitive. It easily 573 rearranges by cyclization into hydroxyfuranes or hydroxypyr- 574 anes. ${ }^{107}$ In this case, only $2 \%$ of hydroxyfuranes was observed. 575 This indicated that our catalyst was not acidic, avoiding the 576 intramolecular reaction. However, the rearrangement of the 577 epoxide into the hydroxyfurane was easily observed when 578 $\mathrm{CDCl}_{3}$ was used for NMR assessments. As an example, only 579 the hydroxyfurane was obtained with a $63 \%$ yield with the 580 previous Eco-Mn, ${ }^{18}$ whereas Pyr-Mn yielded hydroxypyran. ${ }^{108}{ }_{581}$ Therefore, Eco-CaMnO${ }_{x}$ allowed the preparation of very 582 sensitive epoxides. The higher chemoselectivity of Eco- 583 $\mathrm{CaMnO}_{x}$ is the direct consequence of its preparation by a 584 sole thermal treatment. This result is of interest, as linalool 585 epoxide is an important molecule in the communication of 586 pollinating insects. ${ }^{109}$ Thirty-four percent of diepoxides were 587 also obtained. This proved the strong oxidizing properties of 588 Eco-CaMnO ${ }_{x}$ as it succeeded in epoxidizing a terminal double 589 bond.

The monoepoxide was the only one identified with $\alpha$ - and $\beta$ - 591 ionones. The only other byproduct formed during the reaction 592 on both ionones was the product of allylic oxidation, with 12593 and $30 \%$ of selectivity, respectively (Table 5, entries 7,8 ). 594

The other particularly noteworthy example was the 595 epoxidation of oleic acid (Table 5, entry 9). Indeed, epoxides 596 
Table 6. Recycling Studies of Eco-CaMnO ${ }_{x}$ Catalysts
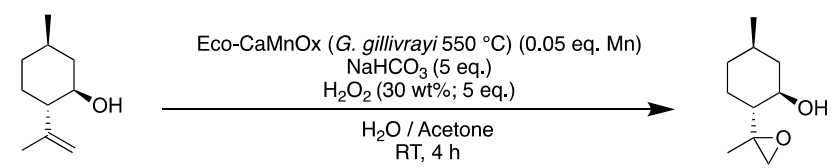

1d

2d

\begin{tabular}{cccccc} 
entry & run & conversion $(\%)$ & yield $(\%)$ & selectivity $(\%)$ & post-run Mn content $($ wt $\%( \pm$ sd) $)$ \\
\hline 1 & no 1 & $>99$ & $>99$ & 100 & $11.22(0.40)$ \\
2 & no 2 & $>99$ & $>99$ & 100 & $11.82(2.20)$ \\
3 & no 3 & 79 & 79 & 100 & $8.93(1.80)$ \\
4 & no 4 & 73 & 73 & 100 & $10.80(0.81)$
\end{tabular}

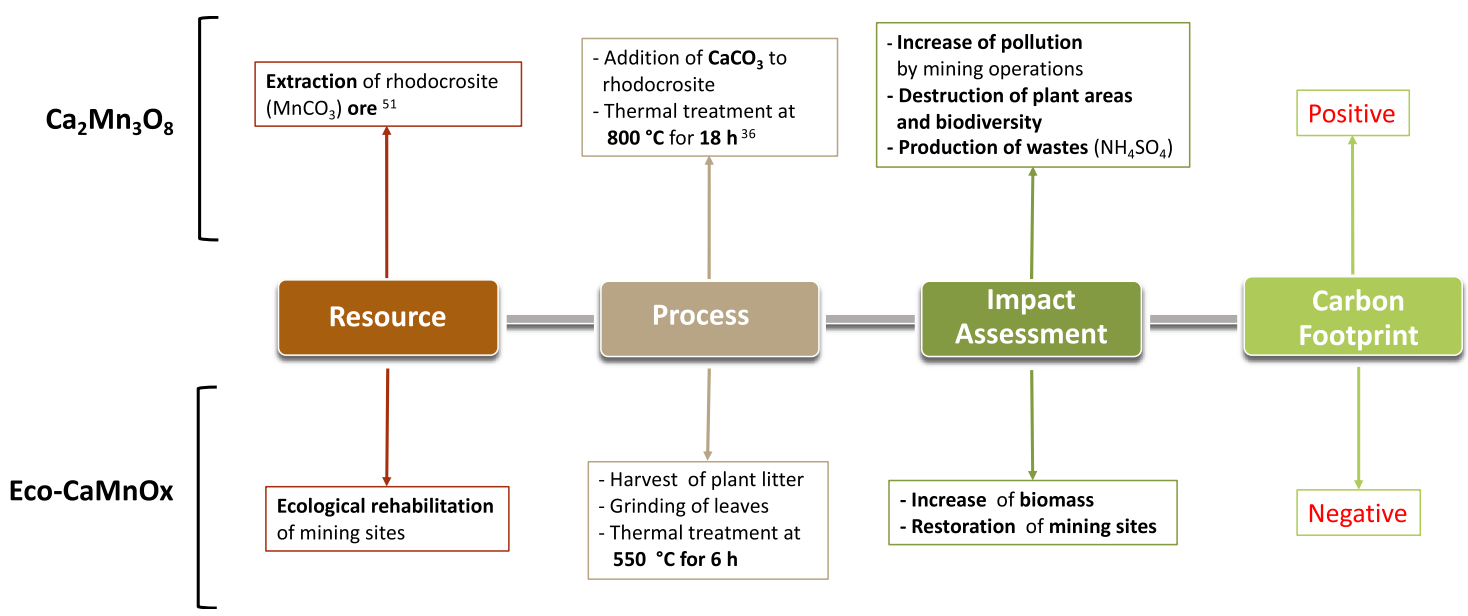

Figure 7. Qualitative environmental impact assessment of the catalyst preparation.

597 of fatty acids from vegetal oils are very interesting as platform 598 molecules for organic chemistry, but also as biodegradable 599 lubricants, plasticizers, and stabilizers of polymers. ${ }^{110-112}$ 600 Sixty-six percent of conversion with a total selectivity in 601 epoxide was reached in $4 \mathrm{~h}$ with $\mathrm{Eco}^{-\mathrm{CaMnO}_{x}}(0.5$ equiv $\mathrm{Mn})$, 602 while Eco-Mn was not able to catalyze this reaction. Pyr-Mn 603 seemed more efficient than $\mathrm{Eco}-\mathrm{CaMnO}_{x}$ but required twice as 604 much $\mathrm{H}_{2} \mathrm{O}_{2}$.

605 In addition to the higher reactivity of Eco-CaMnO$x$ 606 compared to Eco-Mn, the experimental conditions were also 607 improved; epoxidations were conducted with acetone $/ \mathrm{H}_{2} \mathrm{O}$ 608 instead of DMF. In a context of growing environmental 609 consciousness, it is motivating to be able to propose novel 610 catalysts, which combine efficiency, use of renewable resources, 611 and eco-friendly processes.

612 Recycling and Leaching Studies of Eco-CaMnO ${ }_{x}$ Cata613 lysts. Recycling of Eco-CaMnO${ }_{x}$ catalysts was investigated by 614 conducting the epoxidation of isopulegol (Table 6). Eco$615 \mathrm{CaMnO}_{x}$ catalysts were recycled by separation after 616 centrifugation of the crude, washing, drying, and reuse for an 617 identical experiment. Up to four successive reactions were 618 conducted. Conversion and yield remained quantitative for the 619 second run (Table 6, entries 1, 2), while a slight decrease was 620 observed after the third run (Table 6, entries 3,4), suggesting a 621 small loss of activity of Eco- $\mathrm{CaMnO}_{x}$ catalysts.

622 The small loss of activity was investigated by analyzing the 623 composition and structure of Eco- $\mathrm{CaMnO}_{x}$ catalysts after each 624 run. No significant change of $\mathrm{Mn}$ and $\mathrm{Ca}$ contents was 625 observed by MP-AES (Table S2), and the structure 626 characterized by XRPD remained the same. Both results indicated the high stability of Eco-CaMnO${ }_{x}$ catalysts, even in 627 the oxidizing conditions of the reaction. 628

Considering that the composition and structure of Eco- 629 $\mathrm{CaMnO}_{x}$ remained similar after four runs, leaching of Eco- 630 $\mathrm{CaMnO}_{x}$ was unlikely to occur but was still verified. Using 631 isopulegol as substrate, a specific experiment was conducted as 632 described by Sheldon et al. ${ }^{113}$ After $30 \mathrm{~min}$ of reaction, Eco- 633 $\mathrm{CaMnO}_{x}$ was removed from the reaction mixture by filtration; 634 conversion of isopulegol was analyzed after this time at 35\%. 635 The reaction mixture was stirred for another $4 \mathrm{~h}$ without Eco- 636 $\mathrm{CaMnO}_{x}$; conversion of isopulegol remained at 35\%,637 indicating that the reaction did not occur after removing 638 Eco-CaMnO ${ }_{x}$. As expected, the elemental composition of the 639 reaction mixture was analyzed by MP-AES and no trace of 640 metal was detected. These two results showed that the Eco- 641 $\mathrm{CaMnO}_{x}$ catalyst was a heterogeneous catalyst, in which 642 leaching of $\mathrm{Mn}$ can be excluded in the reported conditions. $\quad 643$

\section{CONCLUSIONS}

644

In this study, a new generation of ecocatalysts was easily 645 prepared from Mn-accumulating plant species, which are used 646 in ecological restoration. A controlled thermal treatment of 647 Mn-rich biomass led directly to green oxidative catalysts, Eco- 648 $\mathrm{CaMnO}_{x}$, thus avoiding any further chemical activation. 649 Characterization by MP-AES, XRPD, HRTEM, and STEM- 650 EDX revealed an original polymetallic system. Unusual mixed 651 manganese-calcium oxides, $\mathrm{Ca}_{2} \mathrm{Mn}_{3} \mathrm{O}_{8}$ and $\mathrm{CaMnO}_{3}$, were 652 identified. All Eco-CaMnO${ }_{x}$ catalysts prepared from different 653 plant species demonstrated an excellent catalytic potential in 654 the epoxidation of terpenes and lipids, with only 0.005 equiv 655 
$656 \mathrm{Mn}$, in short reaction times, at room temperature, using green 657 solvents and without any ligand or activation phase. Eco$658 \mathrm{CaMnO}_{x}$ catalysts afforded much higher conversions and 659 yields than conventional activated manganese dioxide or 660 synthetic $\mathrm{Ca}_{2} \mathrm{Mn}_{3} \mathrm{O}_{8}$. Not only did these results demonstrate 661 the vegetal footprint of Eco-CaMnO $x$ catalysts but also they 662 proved that these catalysts could represent potential substitutes 663 to oxidative reagents inconsistent with the requirements of $664 \mathrm{REACH}$ regulation. A wide range of mono- and diepoxides 665 were efficiently synthesized from terpenes, many of them 666 coming from abundant natural resources. Eco-CaMnO $\mathrm{C}_{x}$ opens 667 a new perspective for the valorization of $\mathrm{Mn}$-rich biomass 668 through the preparation of biosourced monomers for new669 biodegradable polymers. ${ }^{105,106,114}$ This new generation of 670 ecocatalysts exhibits environmental and scientific benefits, 671 suggesting a promising life-cycle analysis (Figure 7). It can 672 drive a new approach of green chemistry with ecological, 673 economic, and social advantages.

\section{ASSOCIATED CONTENT}

\section{SI Supporting Information}

676 The Supporting Information is available free of charge at 677 https://pubs.acs.org/doi/10.1021/acssuschemeng.9b05444.

678 General methods for the characterization of Eco-

$679 \mathrm{CaMnO}_{x}$ and the analysis of the reaction products,

680 MP-AES analyses of Mn-accumulating plant leaves and

681 Eco-CaMnO $x$, NMR analyses, scale-up of the epox-

682 idation of alkene, the study of the leaching of Eco-

$683 \mathrm{CaMnO}_{x}$, recycling of Eco-CaMnO ${ }_{x}(\mathrm{PDF})$

\section{AUTHOR INFORMATION}

\section{Corresponding Author}

686 Claude Grison - Laboratory of Bio-inspired Chemistry and

687 Ecological Innovations (ChimEco), UMR 5021 CNRS,

688 University of Montpellier, 34790 Grabels, France; (1) orcid.org/

689 0000-0002-2687-1520; Email: claude.grison@cnrs.fr

\section{Authors}

691 Camille Bihanic - Laboratory of Bio-inspired Chemistry and 692 Ecological Innovations (ChimEco), UMR 5021 CNRS,

693 University of Montpellier, 34790 Grabels, France

694 Sébastien Diliberto - Institut Jean Lamour, UMR 7198

695 CNRS, University of Lorraine, $57000 \mathrm{Metz}$, France;

696 orcid.org/0000-0002-7766-0205

697 Franck Pelissier - Laboratory of Bio-inspired Chemistry and

698 Ecological Innovations (ChimEco), UMR 5021 CNRS,

699 University of Montpellier, 34790 Grabels, France

700 Eddy Petit - Institut Europeen des Membranes, IEM-UMR

7015635, ENSCM, CNRS, University of Montpellier, 34090

$702 \quad$ Montpellier, France

703 Clotilde Boulanger - Institut Jean Lamour, UMR 7198 CNRS,

$704 \quad$ University of Lorraine, $57000 \mathrm{Metz}$, France

705 Complete contact information is available at:

706 https://pubs.acs.org/10.1021/acssuschemeng.9b05444

707 Notes

708 The authors declare no competing financial interest.

\section{ACKNOWLEDGMENTS}

710 The authors would like to thank the French National Center 711 for Scientific Research (CNRS) for financial support. Both 712 North and South provinces of New Caledonia are acknowl- edged for permissions to harvest New Caledonian Mn- 713 hyperaccumulating plants. In the same way, KNS, SLN, and 714 Dr. Cyril Poullain are acknowledged for the cultivation and 715 harvest of plants in New Caledonia. Erwan Oliviero, from 716 Plateforme Microscopie Electronique et Analytique of 717 University of Montpellier, has our thanks for HRTEM and 718 SEM-EDX analyses. Sci-GuidEdit is acknowledged for writing 719 assistance and proofreading the article.

720

\section{REFERENCES}

721

(1) Hunt, A. J.; Farmer, T. J.; Clark, J. H. Elemental Sustainability 722 and the Importance of Scarce Element Recovery. In RSC Green 723 Chemistry; Hunt, A., Ed.; Royal Society of Chemistry: Cambridge, 724 2013; Chapter 1, pp 1-28.

(2) Ecology of Industrial Pollution, 1st ed.; Batty, L. C.; Hallberg, K. 726 B., Eds.; Cambridge University Press: Cambridge, NY, 2010.

(3) Myers, N. Threatened Biotas: "Hot Spots" in Tropical Forests. 728 Environmentalist 1988, 8, 187-208.

(4) US Geological Survey \& Orienteering S. Mineral Commodity 730 Summaries; Government Printing Office, 2009; p 112.

(5) Robineau, B.; Berthault, L.; Christmann, P. Nouvelle-Calédonie, 732 Terre de Nickel. Geosicences 2011, 50-57.

(6) Jaffré, T.; Latham, M.; Schmid, M. Aspects de l'influence de 734 l'extraction du minerai de nickel sur la végétation et les sols en 735 Nouvelle-Calédonie. Cah. O.R.S.T.O.M., Ser. Biol. 1977, 12, 307-321. 736

(7) Losfeld, G.; L'Huillier, L.; Fogliani, B.; Jaffré, T.; Grison, C. 737 Mining in New Caledonia: Environmental Stakes and Restoration 738 Opportunities. Environ. Sci. Pollut. Res. 2015, 22, 5592-5607. 739

(8) Gunkel-Grillon, P.; Laporte-Magoni, C.; Lemestre, M.; Bazire, 740 N. Toxic Chromium Release from Nickel Mining Sediments in 741 Surface Waters, New Caledonia. Environ. Chem. Lett. 2014, 12, 511- 742 516.

(9) Isnard, S.; L'huillier, L.; Rigault, F.; Jaffré, T. How Did the 744 Ultramafic Soils Shape the Flora of the New Caledonian Hotspot? 745 Plant Soil 2016, 403, 53-76.

(10) Pillon, Y.; Munzinger, J.; Amir, H.; Lebrun, M. Ultramafic Soils 747 and Species Sorting in the Flora of New Caledonia. J. Ecol. 2010, 98, 748 $1108-1116$.

(11) Reeves, R. D. Tropical Hyperaccumulators of Metals and Their 750 Potential for Phytoextraction. Plant Soil 2003, 249, 57-65. 751

(12) Losfeld, G.; Mathieu, R.; L’Huillier, L.; Fogliani, B.; Jaffré, T.; 752 Grison, C. Phytoextraction from Mine Spoils: Insights from New 753 Caledonia. Environ. Sci. Pollut. Res. 2015, 22, 5608-5619. 754

(13) Losfeld, G.; L'Huillier, L.; Fogliani, B.; Mc Coy, S.; Grison, C.; 755 Jaffré, T. Leaf-Age and Soil-Plant Relationships: Key Factors for 756 Reporting Trace-Elements Hyperaccumulation by Plants and Design 757 Applications. Environ. Sci. Pollut. Res. 2015, 22, 5620-5632. 758

(14) Grison, C. Combining Phytoextraction and Ecocatalysis: A 759 Novel Concept for Greener Chemistry, an Opportunity for 760 Remediation. Environ. Sci. Pollut. Res. 2015, 22, 5589-5591. 761

(15) Deyris, P.-A.; Grison, C. Nature, Ecology and Chemistry: An 762 Unusual Combination for a New Green Catalysis, Ecocatalysis. Curr. 763 Opin. Green Sustainable Chem. 2018, 10, 6-10.

764

(16) Escande, V.; Renard, B.-L.; Grison, C. Lewis Acid Catalysis and 765 Green Oxidations: Sequential Tandem Oxidation Processes Induced 766 by Mn-Hyperaccumulating Plants. Environ. Sci. Pollut. Res. 2015, 22, 767 5633-5652.

(17) Escande, V.; Lam, C. H.; Grison, C.; Anastas, P. T. EcoMnOx, 769 a Biosourced Catalyst for Selective Aerobic Oxidative Cleavage of 770 Activated 1,2-Diols. ACS Sustainable Chem. Eng. 2017, 5, 3214-3222. 771

(18) Escande, V.; Petit, E.; Garoux, L.; Boulanger, C.; Grison, C. 772 Switchable Alkene Epoxidation/Oxidative Cleavage with $\mathrm{H}_{2} \mathrm{O}_{2} 773$ $/ \mathrm{NaHCO}_{3}$ : Efficient Heterogeneous Catalysis Derived from Bio- 774 sourced Eco-Mn. ACS Sustainable Chem. Eng. 2015, 3, 2704-2715. 775 (19) Escande, V.; Lam, C. H.; Coish, P.; Anastas, P. T. 776 Heterogeneous Sodium-Manganese Oxide Catalyzed Aerobic Oxida- 777 tive Cleavage of 1,2-Diols. Angew. Chem., Int. Ed. 2017, 56, 9561- 778 9565. 
780 (20) Escande, V.; Velati, A.; Garel, C.; Renard, B.-L.; Petit, E.; 781 Grison, C. Phytoextracted Mining Wastes for Ecocatalysis: Eco-Mn, 782 an Efficient and Eco-Friendly Plant-Based Catalyst for Reductive 783 Amination of Ketones. Green Chem. 2015, 17, 2188-2199.

784 (21) Escande, V.; Poullain, C.; Clavé, G.; Petit, E.; Masquelez, N.; 785 Hesemann, P.; Grison, C. Bio-Based and Environmental Input for 786 Transfer Hydrogenation Using $\operatorname{EcoNi}(0)$ Catalyst in Isopropanol. 787 Appl. Catal., B 2017, 210, 495-503.

788 (22) Deyris, P.-A.; Adler, P.; Petit, E.; Legrand, Y.-M.; Grison, C. 789 Woody Species: A New Bio-Based Material for Dual Ca/Mg Catalysis 790 with Remarkable Lewis Acidity Properties. Green Chem. 2019, 21, $7913133-3142$.

792 (23) Deyris, P.-A.; Bert, V.; Diliberto, S.; Boulanger, C.; Petit, E.; 793 Legrand, Y.-M.; Grison, C. Biosourced Polymetallic Catalysis: A 794 Surprising and Efficient Means to Promote the Knoevenagel 795 Condensation. Front. Chem. 2018, 6, 48.

796 (24) Escande, V.; Olszewski, T. K.; Grison, C. From Biodiversity to 797 Catalytic Diversity: How to Control the Reaction Mechanism by the 798 Nature of Metallophytes. Environ. Sci. Pollut. Res. 2015, 22, 56537995666

800 (25) Grison, C. M.; Velati, A.; Escande, V.; Grison, C. Metallophytes 801 for Organic Synthesis: Towards New Bio-Based Selective Protection/ 802 Deprotection Procedures. Environ. Sci. Pollut. Res. 2015, 22, 56868035698

804 (26) Escande, V.; Velati, A.; Grison, C. Ecocatalysis for $2 \mathrm{H}$ 805 Chromenes Synthesis: An Integrated Approach for Phytomanagement 806 of Polluted Ecosystems. Environ. Sci. Pollut. Res 2015, 22, 5677-5685. 807 (27) Escande, V.; Olszewski, T. K.; Petit, E.; Grison, C. Biosourced 808 Polymetallic Catalysts: An Efficient Means To Synthesize Under809 exploited Platform Molecules from Carbohydrates. ChemSusChem 810 2014, 7, 1915-1923.

811 (28) Escande, V.; Olszewski, T. K.; Grison, C. Preparation of 812 Ecological Catalysts Derived from Zn Hyperaccumulating Plants and 813 Their Catalytic Activity in Diels-Alder Reaction. C. R. Chim. 2014, 814 17, 731-737.

815 (29) Olszewski, T. K.; Adler, P.; Grison, C. Bio-Based Catalysts from 816 Biomass Issued after Decontamination of Effluents Rich in Copper817 An Innovative Approach towards Greener Copper-Based Catalysis. 818 Catalysts 2019, 9, 214.

819 (30) Clavé, G.; Pelissier, F.; Campidelli, S.; Grison, C. Ecocatalyzed 820 Suzuki Cross Coupling of Heteroaryl Compounds. Green Chem. 2017, 821 19, 4093-4103.

822 (31) Garel, C.; Renard, B.-L.; Escande, V.; Galtayries, A.; Hesemann, 823 P.; Grison, C. CC Bond Formation Strategy through Ecocatalysis: 824 Insights from Structural Studies and Synthetic Potential. Appl. Catal., 825 A 2015, 504, 272-286.

826 (32) Garel, C.; Fonda, E.; Michalowicz, A.; Diliberto, S.; Boulanger, 827 C.; Petit, E.; Legrand, Y. M.; Poullain, C.; Grison, C. Structure and 828 Composition of First Biosourced Mn-Rich Catalysts with a Unique 829 Vegetal Footprint. Mater. Today Sustainability 2019, No. 100020.

830 (33) Amini, M.; Najafpour, M. M.; Nayeri, S.; Pashaei, B.; 831 Bagherzadeh, M. Nano-Layered Manganese Oxides as Low-Cost, 832 Easily Synthesized, Environmentally Friendly and Efficient Catalysts 833 for Epoxidation of Olefins. RSC Adv. 2012, 2, 3654-3657.

834 (34) Amini, M.; Najafpour, M. M.; Zare, M.; Amini, E. Nanolayered 835 Manganese-Calcium Oxide as an Efficient and Environmentally 836 Friendly Catalyst for Alcohol Oxidation. J. Mol. Catal. A: Chem. 837 2014, 394, 303-308.

838 (35) Bricker, T. M.; Ghanotakis, D. F. Introduction to Oxygen 839 Evolution and the Oxygen-Evolving Complex. In Oxygenic Photosyn840 thesis: The Light Reactions; Advances in Photosynthesis and Respiration; 841 Springer: Dordrecht, 1996; pp 113-136.

842 (36) Park, Y. J.; Doeff, M. M. Synthesis and Electrochemical 843 Characterization of $\mathrm{M} 2 \mathrm{Mn} 3 \mathrm{O} 8(\mathrm{M}=\mathrm{Ca}, \mathrm{Cu})$ Compounds and 844 Derivatives. Solid State Ionics 2006, 177, 893-900.

845 (37) Ramírez, A.; Bogdanoff, P.; Friedrich, D.; Fiechter, S. Synthesis 846 of Ca2Mn3O8 Films and Their Electrochemical Studies for the 847 Oxygen Evolution Reaction (OER) of Water. Nano Energy 2012, 1, $848282-289$.
(38) Najafpour, M. M.; Pashaei, B.; Nayeri, S. Calcium Manganese- 849 (IV) Oxides: Biomimetic and Efficient Catalysts for Water Oxidation. 850 Dalton Trans. 2012, 41, 4799-4805.

851

(39) Dent Glasser, L. S.; Smith, I. B. Oriented Transformations in 852 the System MnO-O- $\mathrm{H}_{2} \mathrm{O}$. Mineral. Mag. J. Mineral. Soc. 1968, 36, 853 976-987.

854

(40) Büchel, K. H.; Moretto, H.-H.; Werner, D. Manganese 855 Compounds and Manganese. In Industrial Inorganic Chemistry, 2nd 856 ed.; John Wiley \& Sons, 2000; pp 282-293.

857

(41) Han, X.; Zhang, T.; Du, J.; Cheng, F.; Chen, J. Porous 858 Calcium-Manganese Oxide Microspheres for Electrocatalytic Oxygen 859 Reduction with High Activity. Chem. Sci. 2012, 4, 368-376. 860

(42) Ansell, G. B.; Modrick, M. A.; Longo, J. M.; Poeppeimeler, K. 861 R.; Horowitz, H. S. Structure of Calcium Manganese Oxide 862 Ca2Mn3O8. Acta Crystallogr., Sect. B: Struct. Crystallogr. Cryst. 863 Chem. 1982, 38, 1795-1797.

(43) Brudvig, G. W. Water Oxidation Chemistry of Photosystem II. 865 Philos. Trans. R. Soc., B 2008, 363, 1211-1219.

(44) Najafpour, M. M.; Ghobadi, M. Z.; Haghighi, B.; Eaton-Rye, J. 867 J.; Tomo, T.; Shen, J.-R.; Allakhverdiev, S. I. Nano-Sized Manganese- 868 Calcium Cluster in Photosystem II. Biochemistry 2014, 79, 324-336. 869 (45) Sienel, G.; Rieth, R.; Rowbottom, K. T. Epoxides. In Ullmann's 870 Encyclopedia of Industrial Chemistry; American Cancer Society, 2000. 871

(46) Adam, W.; Saha-Möller, C. R.; Zhao, C.-G. Dioxirane 872 Epoxidation of Alkenes. In Oxidation of Organic Compounds by 873 Dioxiranes; John Wiley \& Sons, Ltd, 2014; pp 1-309. 874

(47) Bellucci, G.; Chiappe, C.; Moro, G. L.; Ingrosso, G. Facial 875 Stereoselectivity of Two-Step Additions Initiated by Electrophilic 876 Halogens to Methylenecyclohexanes. A Comparison with Epoxida- 877 tion. J. Org. Chem. 1995, 60, 6214-6217. 878

(48) Noyori, R.; Aoki, M.; Sato, K. Green Oxidation with Aqueous 879 Hydrogen Peroxide. Chem. Commun. 2003, 1977-1986. 880

(49) Joergensen, K. A. Transition-Metal-Catalyzed Epoxidations. 881 Chem. Rev. 1989, 89, 431-458.

(50) Grigoropoulou, G.; Clark, J. H.; Elings, J. A. Recent 883 Developments on the Epoxidation of Alkenes Using Hydrogen 884 Peroxide as an Oxidant. Green Chem. 2003, 5, 1-7. 885

(51) Lane, B. S.; Burgess, K. Metal-Catalyzed Epoxidations of 886 Alkenes with Hydrogen Peroxide. Chem. Rev. 2003, 103, 2457-2474. 887 (52) Herrmann, W. A.; Fischer, R. W.; Rauch, M. U.; Scherer, W. 888 Alkylrhenium Oxides as Homogeneous Epoxidation Catalysts: 889 Activity, Selectivity, Stability, Deactivation. J. Mol. Catal. 1994, 86, 890 243-266.

891

(53) Rudolph, J.; Reddy, K. L.; Chiang, J. P.; Sharpless, K. B. Highly 892 Efficient Epoxidation of Olefins Using Aqueous H2O2 and Catalytic 893 Methyltrioxorhenium/Pyridine: Pyridine-Mediated Ligand Acceler- 894 ation. J. Am. Chem. Soc. 1997, 119, 6189-6190.

(54) Owens, G. S.; Durazo, A.; Abu-Omar, M. M. Kinetics of MTO- 896 Catalyzed Olefin Epoxidation in Ambient Temperature Ionic Liquids: 897 UV/Vis and 2H NMR Study. Chem. - Eur. J. 2002, 8, 3053-3059. 898

(55) Yamazaki, S. An Effective Procedure for the Synthesis of Acid- 899 Sensitive Epoxides: Use of 1-Methylimidazole as the Additive on 900 Methyltrioxorhenium-Catalyzed Epoxidation of Alkenes with Hydro- 901 gen Peroxide. Org. Biomol. Chem. 2010, 8, 2377-2385. 902

(56) Conte, V.; Di Furia, F.; Licini, G. Liquid Phase Oxidation 903 Reactions by Peroxides in the Presence of Vanadium Complexes. 904 Appl. Catal., A 1997, 157, 335-361.

(57) Bortolini, O.; Di Furia, F.; Schrimin, P.; Modena, G. Metal 906 Catalysis in Oxidation by Peroxides Part 8 [1] Further Insight on the 907 Mechanism of Vanadium(V) Catalyzed Oxidation of Sulphides and 908 Alkenes by Hydrogen Peroxide. J. Mol. Catal. 1980, 7, 59-74. 909

(58) Dinoi, C.; Ciclosi, M.; Manoury, E.; Maron, L.; Perrin, L.; Poli, 910 R. Olefin Epoxidation by $\mathrm{H} 2 \mathrm{O} 2 / \mathrm{MeCN}$ Catalysed by 911 Cyclopentadienyloxidotungsten(VI) and Molybdenum(VI) Com- 912 plexes: Experiments and Computations. Chem. - Eur. J. 2010, 16, 913 9572-9584.

914

(59) Griffith, W. P.; Parkin, B. C.; White, A. J. P.; Williams, D. J. The 915 Crystal Structures of $[\mathrm{NMe} 4] 2[(\mathrm{PhPO} 3)\{\mathrm{MoO}(\mathrm{O} 2) 2\} 2-\{\mathrm{MoO}-916$ $(\mathrm{O} 2) 2(\mathrm{H} 2 \mathrm{O})\}]$ and $[\mathrm{NBun} 4] 2[\mathrm{~W} 4 \mathrm{O} 6(\mathrm{O} 2) 6(\mathrm{OH} 2)(\mathrm{H} 2 \mathrm{O}) 2]$ and 917 
918 Their Use as Catalytic Oxidants. J. Chem. Soc., Dalton Trans. 1995, 919 3131-3138.

920 (60) Gresley, N. M.; Griffith, W. P.; Laemmel, A. C.; Nogueira, H. I. 921 S.; Parkin, B. C. Studies on Polyoxo and Polyperoxo-Metalates Part 922 511Part 4: Ref. [4].: Peroxide-Catalysed Oxidations with Hetero923 polyperoxo-Tungstates and -Molybdates. J. Mol. Catal. A: Chem. 924 1997, 117, 185-198.

925 (61) Venturello, C.; Alneri, E.; Ricci, M. A New, Effective Catalytic 926 System for Epoxidation of Olefins by Hydrogen Peroxide under 927 Phase-Transfer Conditions. J. Org. Chem. 1983, 48, 3831-3833.

928 (62) Sato, K.; Aoki, M.; Ogawa, M.; Hashimoto, T.; Noyori, R. A 929 Practical Method for Epoxidation of Terminal Olefins with 30\% 930 Hydrogen Peroxide under Halide-Free Conditions. J. Org. Chem. 931 1996, 61, 8310-8311.

932 (63) Villa de P, A. L.; Sels, B. F.; De Vos, D. E.; Jacobs, P. A. A 933 Heterogeneous Tungsten Catalyst for Epoxidation of Terpenes and 934 Tungsten-Catalyzed Synthesis of Acid-Sensitive Terpene Epoxides. J. 935 Org. Chem. 1999, 64, 7267-7270.

936 (64) Kamata, K.; Sugahara, K.; Ishimoto, R.; Nojima, S.; Okazaki, 937 M.; Matsumoto, T.; Mizuno, N. Highly Selective Epoxidation of 938 Cycloaliphatic Alkenes with Aqueous Hydrogen Peroxide Catalyzed 939 by [PO4WO(O2)24]3-/Imidazole. ChemCatChem 2014, 6, 23279402332.

941 (65) Gerber, G. B.; Léonard, A.; Hantson, P. Carcinogenicity, 942 Mutagenicity and Teratogenicity of Manganese Compounds. Crit. 943 Rev. Oncol. Hematol. 2002, 42, 25-34.

944 (66) 24-Manganese, Technetium and Rhenium. In Chemistry of the 945 Elements, 2nd ed.; Greenwood, N. N.; Earnshaw, A., Eds.; Butter946 worth-Heinemann: Oxford, 1997; pp 1040-1069.

947 (67) Anelli, P. L.; Banfi, S.; Montanari, F.; Quici, S. Synergistic 948 Effect of Lipophilic Carboxylic Acids and Heterocyclic Axial Ligands 949 in Alkene Epoxidation by Hydrogen Peroxide Catalysed by 950 Manganese(III) Tetra-Aryl Porphyrins. J. Chem. Soc., Chem. Commun. 951 1989, 779-780.

952 (68) Banfi, S.; Legramandi, F.; Montanari, F.; Pozzi, G.; Quici, S. 953 Biomimetic Models of Cytochrome P-450. A Doubly Tailed 954 Manganese(III)-Tetraaryl Porphyrin; an Extremely Efficient Catalyst 955 for Hydrocarbon Oxygenations Promoted by 30\% H2O2. J. Chem. 956 Soc., Chem. Commun. 1991, 1285-1287.

957 (69) Maraval, V.; Ancel, J.-E.; Meunier, B. Manganese(III) 958 Porphyrin Catalysts for the Oxidation of Terpene Derivatives: A 959 Comparative Study. J. Catal. 2002, 206, 349-357.

960 (70) Martins, R. R. L.; Neves, M. G. P. M. S.; Silvestre, A. J. D.; 961 Simões, M. M. Q.; Silva, A. M. S.; Tomé, A. C.; Cavaleiro, J. A. S.; 962 Tagliatesta, P.; Crestini, C. Oxidation of Unsaturated Monoterpenes 963 with Hydrogen Peroxide Catalysed by Manganese(III) Porphyrin 964 Complexes. J. Mol. Catal. A: Chem. 2001, 172, 33-42.

965 (71) Berkessel, A.; Frauenkron, M.; Schwenkreis, T.; Steinmetz, A.; 966 Baum, G.; Fenske, D. Pentacoordinated Manganese(III) Dihydrosalen 967 Complexes as Biomimetic Oxidation Catalysts. J. Mol. Catal. A: Chem. 968 1996, 113, 321-342.

969 (72) Pietikäinen, P. Convenient Asymmetric (Salen)Mn(III)970 Catalyzed Epoxidation of Unfunctionalized Alkenes with Hydrogen 971 Peroxide Using Carboxylate Salt Cocatalysts. Tetrahedron 1998, 54, 972 4319-4326.

973 (73) Zhang, W.; Loebach, J. L.; Wilson, S. R.; Jacobsen, E. N. 974 Enantioselective Epoxidation of Unfunctionalized Olefins Catalyzed 975 by Salen Manganese Complexes. J. Am. Chem. Soc. 1990, 112, 28019762803.

977 (74) Katsuki, T. Mn-Salen Catalyst, Competitor of Enzymes, for 978 Asymmetric Epoxidation. J. Mol. Catal. A: Chem. 1996, 113, 87-107. 979 (75) Ito, Y. N.; Katsuki, T. What Is the Origin of Highly Asymmetric 980 Induction by a Chiral (Salen)Manganese(III) Complex? Design of a 981 Conformationally Fixed Complex and Its Application to Asymmetric 982 Epoxidation of 2, 2-Dimethylchromenes. Tetrahedron Lett. 1998, 39, $9834325-4328$.

984 (76) Serra, A. C.; Marçalo, E. C.; Gonsalves, A. D. A View on the 985 Mechanism of Metalloporphyrin Degradation in Hydrogen Peroxide 986 Epoxidation Reactions. J. Mol. Catal. A: Chem. 2004, 215, 17-21.
(77) Zammataro, A.; Gangemi, C. M. A.; Pappalardo, A.; Toscano, 987 R. M.; Puglisi, R.; Nicotra, G.; Fragalà, M. E.; Tuccitto, N.; Sfrazzetto, 988 G. T. Covalently Functionalized Carbon Nanoparticles with a Chiral 989 Mn-Salen: A New Nanocatalyst for Enantioselective Epoxidation of 990 Alkenes. Chem. Commun. 2019, 55, 5255-5258.

(78) Martinez-Lorente, M. A.; Battioni, P.; Kleemiss, W.; Bartoli, J. 992 F.; Mansuy, D. Manganese Porphyrins Covalently Bound to Silica and 993 Montmorillonite K10 as Efficient Catalysts for Alkene and Alkane 994 Oxidation by Hydrogen Peroxide. J. Mol. Catal. A: Chem. 1996, 113, 995 343-353.

996

(79) Doro, F. G.; Smith, J. R. L.; Ferreira, A. G.; Assis, M. D. 997 Oxidation of Alkanes and Alkenes by Iodosylbenzene and Hydrogen 998 Peroxide Catalysed by Halogenated Manganese Porphyrins in 999 Homogeneous Solution and Covalently Bound to Silica. J. Mol. 1000 Catal. A: Chem. 2000, 164, 97-108.

1001

(80) Beigi, M.; Roller, S.; Haag, R.; Liese, A. Polyglycerol-Supported 1002 Co- and Mn-Salen Complexes as Efficient and Recyclable 1003 Homogeneous Catalysts for the Hydrolytic Kinetic Resolution of 1004 Terminal Epoxides and Asymmetric Olefin Epoxidation. Eur. J. Org. 1005 Chem. 2008, 2008, 2135-2141.

1006

(81) Arpe, H.-J. Industrial Organic Chemistry, 5th Completely 1007 Revised Edition; Wiley-VCH Verlag GmnH \& Co. KGaA: Weinheim, 1008 Germany, 2016.

1009

(82) Lane, B. S.; Vogt, M.; DeRose, V. J.; Burgess, K. Manganese- 1010 Catalyzed Epoxidations of Alkenes in Bicarbonate Solutions. J. Am. 1011 Chem. Soc. 2002, 124, 11946-11954.

1012

(83) Lane, B. S.; Burgess, K. A Cheap, Catalytic, Scalable, and 1013 Environmentally Benign Method for Alkene Epoxidations. J. Am. 1014 Chem. Soc. 2001, 123, 2933-2934.

1015

(84) Bauer, K.; Garbe, D.; Surburg, H. Single Fragrance and Flavor 1016 Materials. In Common Fragrance and Flavor Materials; John Wiley \& 1017 Sons, Ltd, 2001; pp 7-165.

1018

(85) Wender, P. A.; Mucciaro, T. P. A New and Practical Approach 1019 to the Synthesis of Taxol and Taxol Analogs: The Pinene Path. J. Am. 1020 Chem. Soc. 1992, 114, 5878-5879.

1021

(86) Mimoun, H. Catalytic Opportunities in the Flavor and 1022 Fragrance Industry. CHIMIA 1996, 50, 620-625. 1023

(87) Hölderich, W. F.; Röseler, J.; Heitmann, G.; Liebens, A. T. The 1024 Use of Zeolites in the Synthesis of Fine and Intermediate Chemicals. 1025 Catal. Today 1997, 37, 353-366.

1026

(88) Wilson, K.; Rénson, A.; Clark, J. H. Novel Heterogeneous Zinc 1027 Triflate Catalysts for the Rearrangement of $\alpha$-Pinene Oxide. Catal. 1028 Lett. 1999, 61, 51-55.

1029

(89) Kaminska, J.; Schwegler, M. A.; Hoefnagel, A. J.; van Bekkum, 1030 $\mathrm{H}$. The Isomerization of $\alpha$-Pinene Oxide with Brønsted and Lewis 1031 Acids. Recl. Trav. Chim. Pays-Bas 1992, 111, 432-437. 1032

(90) Bleier, D. B.; Elrod, M. J. Kinetics and Thermodynamics of 1033 Atmospherically Relevant Aqueous Phase Reactions of $\alpha$-Pinene 1034 Oxide. J. Phys. Chem. A 2013, 117, 4223-4232. 1035

(91) Stekrova, M.; Kumar, N.; Aho, A.; Sinev, I.; Grünert, W.; Dahl, 1036 J.; Roine, J.; Arzumanov, S. S.; Mäki-Arvela, P.; Murzin, D. Y. 1037 Isomerization of $\alpha$-Pinene Oxide Using Fe-Supported Catalysts: 1038 Selective Synthesis of Campholenic Aldehyde. Appl. Catal., A 2014, 1039 470, 162-176.

1040

(92) Qi, B.; Lu, X.-H.; Zhou, D.; Xia, Q.-H.; Tang, Z.-R.; Fang, S.-Y.; 1041 Pang, T.; Dong, Y.-L. Catalytic Epoxidation of Alkenes with 30\% 1042 $\mathrm{H} 2 \mathrm{O} 2$ over Mn2+-Exchanged Zeolites. J. Mol. Catal. A: Chem. 2010, 1043 322, 73-79.

1044

(93) Fraile, J. M.; Garc1'a, J. I.; Mayoral, J. A.; Vispe, E. Optimization 1045 of Cyclohexene Epoxidation with Dilute Hydrogen Peroxide and 1046 Silica-Supported Titanium Catalysts. Appl. Catal., A 2003, 245, 363- 1047 376.

1048

(94) Timofeeva, M. N.; Kholdeeva, O. A.; Jhung, S. H.; Chang, J.-S. 1049 Titanium and Cerium-Containing Mesoporous Silicate Materials as 1050 Catalysts for Oxidative Cleavage of Cyclohexene with H2O2: A 1051 Comparative Study of Catalytic Activity and Stability. Appl. Catal., A 1052 2008, 345, 195-200. 
1054 (95) Murphy, E. F.; Mallat, T.; Baiker, A. Allylic Oxofunctionaliza1055 tion of Cyclic Olefins with Homogeneous and Heterogeneous 1056 Catalysts. Catal. Today 2000, 57, 115-126.

1057 (96) Menini, L.; Pereira, M. C.; Parreira, L. A.; Fabris, J. D.; 1058 Gusevskaya, E. V. Cobalt- and Manganese-Substituted Ferrites as 1059 Efficient Single-Site Heterogeneous Catalysts for Aerobic Oxidation 1060 of Monoterpenic Alkenes Under Solvent-Free Conditions. J. Catal. 1061 2008, 254, 355-364.

1062 (97) Yao, H.; Richardson, D. E. Epoxidation of Alkenes with 1063 Bicarbonate-Activated Hydrogen Peroxide. J. Am. Chem. Soc. 2000, 1064 122, 3220-3221.

1065 (98) Frank, W. C. Surprising Stereoselectivity in the Payne 1066 Epoxidation of Terpinen-4-Ol with Acetonitrile/Hydrogen Peroxide. 1067 Tetrahedron: Asymmetry 1998, 9, 3745-3749.

1068 (99) Cahiez, G.; Alami, M.; Taylor, R. J. K.; Reid, M.; Foot, J. S. 1069 Manganese Dioxide. In Encyclopedia of Reagents for Organic Synthesis; 1070 John Wiley \& Sons, Ltd: Chichester, 2004.

1071 (100) Raupp, Y. S.; Yildiz, C.; Kleist, W.; Meier, M. A. R. Aerobic 1072 Oxidation of $\alpha$-Pinene Catalyzed by Homogeneous and MOF-Based 1073 Mn Catalysts. Appl. Catal., A 2017, 546, 1-6.

1074 (101) Patil, M. V.; Yadav, M. K.; Jasra, R. V. Catalytic Epoxidation of $1075 \alpha$-Pinene with Molecular Oxygen Using Cobalt(II)-Exchanged 1076 Zeolite Y-Based Heterogeneous Catalysts. J. Mol. Catal. A: Chem. 1077 2007, 277, 72-80.

1078 (102) Parrino, F.; Fidalgo, A.; Palmisano, L.; Ilharco, L. M.; Pagliaro, 1079 M.; Ciriminna, R. Polymers of Limonene Oxide and Carbon Dioxide: 1080 Polycarbonates of the Solar Economy. ACS Omega 2018, 3, 488410814890

1082 (103) Couture, G.; Granado, L.; Fanget, F.; Boutevin, B.; Caillol, S. 1083 Limonene-Based Epoxy: Anhydride Thermoset Reaction Study. 1084 Molecules 2018, 23, 2739.

1085 (104) Bähr, M.; Bitto, A.; Mülhaupt, R. Cyclic Limonene 1086 Dicarbonate as a New Monomer for Non-Isocyanate Oligo- and 1087 Polyurethanes (NIPU) Based upon Terpenes. Green Chem. 2012, 14, 1088 1447-1454.

1089 (105) Longo, J. M.; Sanford, M. J.; Coates, G. W. Ring-Opening 1090 Copolymerization of Epoxides and Cyclic Anhydrides with Discrete 1091 Metal Complexes: Structure-Property Relationships. Chem. Rev. 1092 2016, 116, 15167-15197.

1093 (106) Childers, M. I.; Longo, J. M.; Van Zee, N. J.; LaPointe, A. M.; 1094 Coates, G. W. Stereoselective Epoxide Polymerization and Copoly1095 merization. Chem. Rev. 2014, 114, 8129-8152.

1096 (107) Klein, E.; Farnow, H.; Rojahn, W. Die Chemie der Linalool1097 oxide. Justus Liebigs Ann. Chem. 1964, 675, 73-82.

1098 (108) Bihanic, C.; Stanovych, A.; Pelissier, F.; Grison, C. Putting 1099 Waste to Work: The Demonstrative Example of Pyrite Quarry 1100 Effluents Turned into Green Oxidative Catalysts. ACS Sustainable 1101 Chem. Eng. 2019, 7, 6223-6233.

1102 (109) Raguso, R.; Pichersky, E. New Perspectives in Pollination 1103 Biology: Floral Fragrances. A Day in the Life of a Linalool Molecule: 1104 Chemical Communication in a Plant-Pollinator System. Part 1: 1105 Linalool Biosynthesis in Flowering Plants. Plant Species Biol. 1999, 14, 1106 95-120.

1107 (110) Buisman, G. J. H. Biodegradable Binders and Cross-Linking 1108 Agents from Renewable Resources. Surf. Coat. Int. 1999, 82, 127.

1109 (111) Adhvaryu, A.; Erhan, S. Z. Epoxidized Soybean Oil as a 1110 Potential Source of High-Temperature Lubricants. Ind. Crops Prod. $11112002,15,247-254$.

1112 (112) Joseph, R.; Madhusoodhanan, K. N.; Alex, R.; Varghese, S.; 1113 George, K. E.; Kuriakose, B. Studies on Epoxidised Rubber Seed Oil 1114 as Secondary Plasticiser/Stabiliser for Polyvinyl Chloride. Plast., 1115 Rubber Compos. 2004, 33, 217-222.

1116 (113) Sheldon, R. A.; Wallau, M.; Arends, I. W. C. E.; Schuchardt, 1117 U. Heterogeneous Catalysts for Liquid-Phase Oxidations: Philoso1118 phers' Stones or Trojan Horses? Acc. Chem. Res. 1998, 31, 485-493. 1119 (114) Robert, C.; De Montigny, F.; Thomas, C. M. Tandem 1120 Synthesis of Alternating Polyesters from Renewable Resources. Nat. 1121 Commun. 2011, 2, No. 586. 